\title{
The instability of continental passive margins and its effect on continental topography and heat flow
}

\author{
J. J. Armitage, ${ }^{1}$ C. Jaupart, ${ }^{1}$ L. Fourel, ${ }^{2}$ and P. A. Allen ${ }^{2}$ \\ Received 28 June 2012; revised 14 January 2013; accepted 16 January 2013; published 29 April 2013.
}

[1] The long geological history of passive margin evolution is complex yet typified by an initial ramp-like tilting of the subaerial surface toward the continent-ocean boundary, followed by episodic uplift and subsidence at a smaller wavelength. We argue that this behavior is due to changes in margin structure brought about by buoyancy-driven lithospheric flow. Continental lithosphere is melt-depleted, buoyant, and thick. It will resist convective breakdown into the asthenosphere below, but will be prone to lateral flow due to horizontal density contrasts. Changes in lithosphere thickness at the transition between continent and ocean will nucleate convection cells. Using a numerical model of viscous upper mantle flow, we show that stability or instability of the continental lithosphere at a passive margin is a function of the lithospheric rheology and composition. Increased compositional buoyancy leads to oceanward lateral flow of the continental lithosphere whereas decreased buoyancy has the opposite effect, causing landward lateral flow of the continental lithosphere. In model simulations, a continental lithosphere thought typical of Phanerozoic continental platforms experiences first a margin-wide ramp-like tilting, followed by topographic fluctuations due to an evolving array of convection cells in the mantle. The timing and magnitude of predicted changes in topography are similar to those observed at the eastern North American margin, suggesting that the tilting and episodic uplift and subsidence at continental passive margins are a natural consequence of the evolution of continental lithosphere after breakup and during mature seafloor spreading.

Citation: Armitage, J. J., C. Jaupart, L. Fourel, and P. A. Allen (2013), The instability of continental passive margins and its effect on continental topography and heat flow, J. Geophys. Res. Solid Earth, 118, 1817-1836, doi:10.1002/jgrb.50097.

\section{Introduction}

[2] It has long been recognized that the continents have a history of changing uplift and subsidence, leading to strong variations in the degree of continental inundation [Sloss, 1963]. Continental margins and adjacent plate interiors preserve a record of large-scale movements of the surface of the Earth in their stratigraphic records. In some examples, such as North America and Northern Africa, an initial largescale tilting is followed by episodes of variable subsidence and erosion at a smaller wavelength (Figure 1) [Allen and Armitage, 2012]. Intracratonic basins and continental interior platforms in South America [Soares et al., 1978; Japsen et al., 2012], Africa [Hartley and Allen, 1994; Crosby et al., 2010; Kadima Kabongo et al., 2011; Buiter et al., 2012], North America [Heller et al., 1982; Poag and Sevon, 1989;

\footnotetext{
${ }^{1}$ Dynamique des Fluids Géologiques, Institut de Physique du Globe de Paris, Paris, France.

${ }^{2}$ Department of Earth Science and Engineering, Imperial College London, London, UK.

Corresponding author: J. J. Armitage, Dynamique des Fluids Géologiques, Univ Paris Diderot, Sorbonne Paris Cité, Institut de Physique du Globe de Paris, UMR 7154 CNRS, F-75013 Paris, France (armitage@ipgp.fr)
}

(C)2013. American Geophysical Union. All Rights Reserved. 2169-9313/13/10.1002/jgrb.50097
Coakley and Gurnis, 1995; Burgess et al., 1997], and Australia [Lindsay et al., 1987; Shaw et al., 1991; Lindsay, 2002], contain a long record of this ever changing topography.

[3] The initiation of subsidence within intracratonic basins is not randomly distributed through time [Klein and Hsui, 1987; Allen and Armitage, 2012], rather there are periods of basin formation that cluster around times of supercontinent breakup and dispersal. Over the last billion years, through two cycles of supercontinent formation and dispersal, there have been two main periods of basin formation, during the Cambrian to Ordovician and during the Permian to Triassic [Allen and Armitage, 2012]. In particular, the North American basins (Oklahoma, Illinois, Michigan) formed during the Cambrian as a large-scale ramp-like tilt toward the ocean, seen in the isopach pattern of the latest Proterozoic-Early Ordovician "Sauk" sequence of eastern North America (Figure 1a) [Sloss, 1963]. At a similar time, the North African region was one extensive ramp, becoming later divided into individual basins [Selley, 1972; Boote et al., 1998]. The broad regional tilting of the continent toward the oceanic domain may be a generic feature of supercontinental breakup and passive margin evolution [Allen and Armitage, 2012]. Cratonic basins later individualized and became the oval- to kidney-shaped depocenters we observe today. These large sedimentary basins and continental platforms have experienced a long history of episodic subsidence. Some periods of increased subsidence have been 
(a) North American Continent

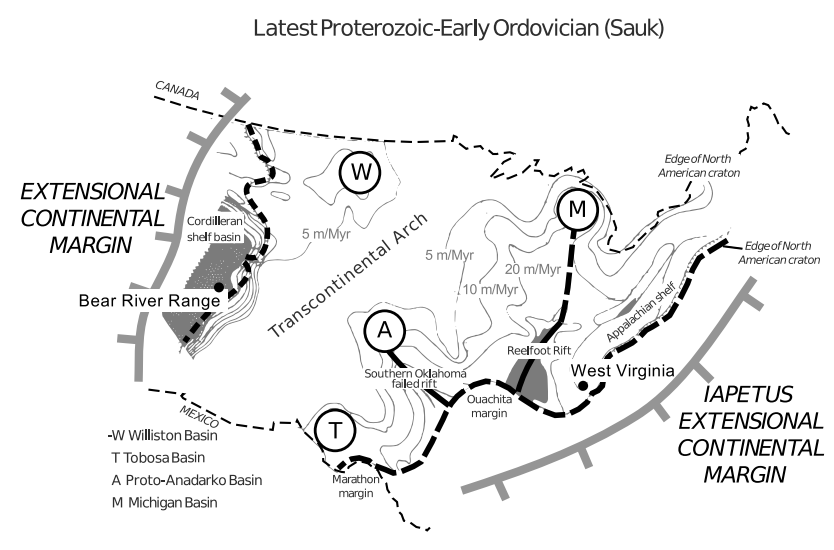

(b) Passive margin/intracratonic subsidence

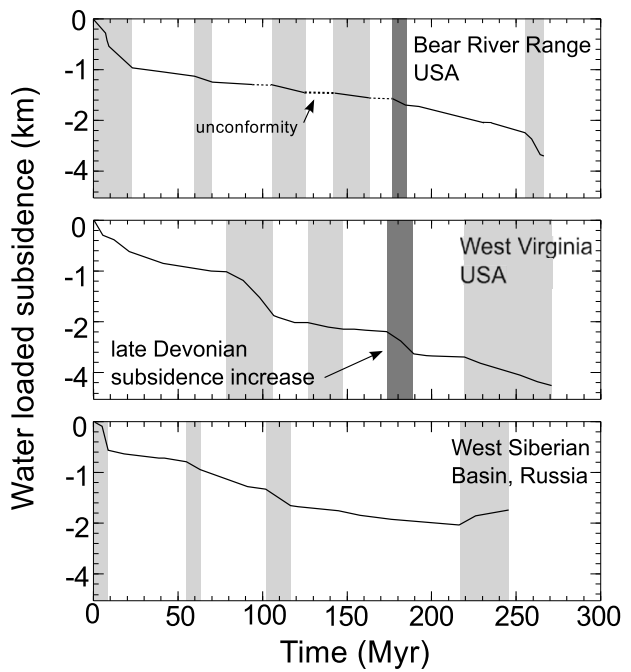

Figure 1. Continental subsidence at the margins. (a) Map of the earliest sedimentary sequence of North America, modified from Sloss [1988]. The Sauk sequences (Latest Proterozoic to Early Ordovician) highlighted in the map shows a region of broad tilting of the continent toward the eastern and western margins. (b) Subsidence plotted against time from the initiation of subsidence for two bore holes representative of the Paleozoic western and eastern North American margins [Bond and Kominz, 1991] and a third from the West Siberian Basin [Saunders et al., 2005]. Periods of increased subsidence are marked in light grey, with the North American wide late Devonian period of subsidence marked in dark grey. Note the first period of faster subsidence may be due to the basin formation mechanism [Armitage and Allen, 2010].

observed across continental land masses (the late Devonian "event"; Figure 1b), while others are more local to individual basins [Bond and Kominz, 1991; Sloss, 1991].

[4] The changing pattern of continental uplift and subsidence has been attributed to different causes, including dynamic topography driven by underlying mantle circulation [Pritchard et al., 2009], slab subduction [Mitrovica et al., 1989; Coakley and Gurnis, 1995; Burgess et al., 1997; Spasojevic et al., 2008; Moucha et al., 2008], and in-plane stresses due to remote tectonic forcing [Bond and Kominz, 1991; Karner, 1985; Cloetingh and Kooi, 1992]. Yet these mechanisms require each change in subsidence to be linked to unique events in the past. The apparent relationship between periods of basin formation and supercontinent breakup and dispersal suggests that the cause may lie in the new continental configurations that are generated. The temporal recurrence of accelerated subsidence and uplift on a wide range of continental margins through the Phanerozoic (Figure 1b) [Heller et al., 1982; Bond and Kominz, 1991; Japsen and Chalmers, 2000] points to a mechanism that is intrinsic to continental margins, independently of largerscale convective and tectonic stresses. At a passive margin, there exists a change from thick and buoyant continental lithosphere to a thinner and less buoyant oceanic lithosphere, a situation that is inherently unstable. How this transition zone evolves will affect margin topography, dimensions, and position.

[5] The potential for lateral gradients in lithosphere thickness to nucleate mantle flow has been studied in the past [King and Anderson, 1998; Shapiro et al., 1999; Nielsen and Hopper, 2004; Sleep, 2007; van Wijk et al., 2008, 2010; Hardebol et al., 2012]. These studies do not consider the density change due to melt depletion when continental lithosphere transitions to oceanic. If continental lithosphere is intrinsically buoyant, then there is a lateral density difference at the continent-ocean transition. In an idealized system, we would expect there to be a lateral gravitationally driven flow, where the continental lithosphere drives into (over, under, or both) the oceanic lithosphere. In the model of Huismans and Beaumont [2011], a thick buoyant root is placed on one side of a rifting margin with a large lateral density contrast $\left(50 \mathrm{~kg} \mathrm{~m}^{-3}\right)$. The lower lithosphere spreads horizontally and rapidly drains into the young rift margin (in less than $15 \mathrm{Myr}$ for the rheological properties used). Similar calculations by Nikolaeva et al. [2011] illustrate the same process of deep lateral lithospheric flow for a range of conditions at the ocean continent transition. But depending on the density contrast and shape of the transition from oceanic to continental lithosphere, this lateral flow will potentially be countered by convection cells that develop at the same time. The dynamic equilibrium that results would lead to observable changes in surface topography, which could be diagnostic of the structure of the lithosphere at the passive margin. Using a 2-D numerical model of highly viscous mantle flow, we explore this phenomenon for different mantle deformation mechanisms of diffusion and dislocation creep. Model results are discussed in relation to the topographic and heat flow history of continental margins and their sedimentary basins.

\section{Methods}

[6] Our modeling strategy is to understand the behavior of an idealized 2-D highly viscous system that represents the continental to oceanic lithosphere transition zone. We wish to understand how the system behaves as we change three 
key control variables: (1) the intrinsic buoyancy contrast between oceanic and continental lithosphere, (2) the width of the transition region between continental and oceanic lithosphere, and (3) the viscous rheology of the lithosphere-asthenosphere system. The aim is to understand the physics of how the transition in temperature and composition at the passive margin affects its geological and topographic evolution.

\subsection{The Transition From Continental to Oceanic Lithosphere}

[7] The depth to the base of the lithosphere depends on how the lithosphere is defined, in terms of thermal, compositional, mechanical, or seismic structure [Jordan, 1981; McKenzie and Bickle, 1988; Goes and van der Lee, 2002]. However, it is clear that lithosphere thickness is greater under the continents than under ocean basins, causing there to be a gradient in thickness across the continental margin. For example, the North American continent has a thermal lithosphere thickness beneath the Archean craton of up to $\sim 250 \mathrm{~km}$ [Jaupart et al., 1998; Lévy and Jaupart, 2011]. From inversions of seismic tomography, the mantle isentrope is not reached until the $200-250 \mathrm{~km}$ depth beneath the stable eastern North America [Goes and van der Lee, 2002]. A change in the characteristics of seismic anisotropy is mapped beneath North America at this approximate depth [Yuan and Romanowicz, 2010]. This can be compared with oceanic lithosphere that has a typical thickness of about $100 \mathrm{~km}$ [Priestly and McKenzie, 2006; Afonso et al., 2007; Korenaga and Korenaga, 2008].

[8] All samples of lithospheric mantle exhumed at the surface of the earth or transported by kimberlite eruptions show evidence of melt depletion [e.g., Jordan, 1975; Poudjom Djomani et al., 2001; Schutt and Lesher, 2006; Griffin et al., 2009]. The ideal continental lithosphere would be isopycnic, where the density change due to melt depletion would completely offset the density change due to temperature [Jordan, 1975]. Such isopycnic conditions are suggested to have secured longevity [Shapiro et al., 1999]. But a complete lack of density contrasts is very hard to maintain in a thermally convecting system. Given the lateral contrast in lithosphere thickness, conductive cooling will lead to lateral density contrasts that will inevitably violate the isopycnic condition. Recent petrological models suggest that continental lithosphere has a density that is somewhat greater than that of the isopycnic ideal [Schutt and Lesher, 2006]. Furthermore, inversions for density from seismic tomography indicate that continental lithosphere is on average less depleted than petrological estimates from small sample suites [Cammarano et al., 2011]. Therefore whilst there can be no doubt that continental lithosphere is intrinsically buoyant, there is less certainty on the degree of buoyancy.

[9] The relationships between the different definitions of lithosphere thickness have filled many pages in the literature [Jaupart et al., 2007] and are beyond the scope of this paper. Unless stated otherwise, the term lithosphere will refer to the melt-depleted boundary layer at the top of the Earth's mantle throughout this paper. Such lithosphere is thinner than the thermal and seismic boundary layers, which are both defined as extending to the mantle isentrope and hence include a thin convective boundary layer beneath the chemically depleted layer.

\subsection{Momentum Balance in the Presence of Intrinsic Buoyancy}

[10] We make the assumption that the upper mantle can be modeled as a viscous fluid solving Stokes equations under the Boussinesq approximation. The numerical methods are as outlined in Nielsen and Hopper [2004] and Armitage et al. [2008]. Flow in the upper mantle is driven by change in density, which is solved for through the momentum balance:

$$
-\frac{\partial \tau_{i j}}{\partial x_{j}}+\frac{\partial p}{\partial x_{i}}=-\Delta \rho \mathrm{g} \lambda_{i}
$$

where upward flow is in the negative $z$ direction (the symbols are given in Table 1). We write the change in density as a function of temperature and depletion as follows:

$$
\Delta \rho=\Delta \rho_{T}+\Delta \rho_{F}=\rho_{0}(\alpha \Delta T+\beta F)
$$

where $\alpha$ is the coefficient of thermal expansion, $\Delta T=T-T_{m}$

\begin{tabular}{|c|c|c|c|}
\hline Parameter & Value & Units & Description \\
\hline$B$ & & & Buoyancy number \\
\hline$d$ & 700 & $\mathrm{~km}$ & Depth to base of model domain \\
\hline$F$ & & & Melt depletion \\
\hline$p$ & & $\mathrm{~Pa}$ & Pressure \\
\hline$T$ & & ${ }^{\circ} \mathrm{C}$ & Temperature \\
\hline$X$ & & & Hypothetical trace element \\
\hline$\eta$ & & Pas & Viscosity \\
\hline$\dot{I}_{2}^{\prime}$ & & & $\begin{array}{l}\text { Dimensionless second invariant of } \\
\text { strain rate }\end{array}$ \\
\hline$\tau$ & & $\mathrm{Pa}$ & Stress \\
\hline$g$ & 9.81 & $\mathrm{~m} \mathrm{~s}^{-2}$ & Acceleration due to gravity \\
\hline$X_{\text {ref }}$ & 1.3 & & Reference depletion \\
\hline$T_{m}$ & 1315 & ${ }^{\circ} \mathrm{C}$ & Mantle potential temperature \\
\hline$\rho_{0}$ & 3340 & $\mathrm{~kg} \mathrm{~m}^{-3}$ & Mantle reference density \\
\hline$\Delta \rho$ & & $\mathrm{kg} \mathrm{m}^{-3}$ & $\begin{array}{l}\text { Change in density due to } \\
\text { temperature and melt depletion }\end{array}$ \\
\hline$\Delta \rho_{T}$ & & $\mathrm{~kg} \mathrm{~m}^{-3}$ & $\begin{array}{l}\text { Change in density due to } \\
\text { temperature }\end{array}$ \\
\hline$\Delta \rho_{F}$ & & $\mathrm{~kg} \mathrm{~m}^{-3}$ & $\begin{array}{l}\text { Change in density due to melt } \\
\text { depletion }\end{array}$ \\
\hline$\Delta \rho_{\text {ref }}$ & & $\mathrm{kg} \mathrm{m}^{-3}$ & $\begin{array}{l}\text { Change in density at reference } \\
\text { depletion }\end{array}$ \\
\hline$\alpha$ & $3.3 \times 10^{-5}$ & $\mathrm{~K}^{-1}$ & Coefficient of thermal expansion \\
\hline$\beta$ & & & $\begin{array}{l}\text { Coefficient of depletion related } \\
\text { density reduction }\end{array}$ \\
\hline$\lambda_{i}$ & & & Unit vector in the vertical \\
\hline$\kappa$ & $10^{-6}$ & $\mathrm{~m}^{2} \mathrm{~s}^{-1}$ & Thermal diffusivity \\
\hline$\eta_{0}$ & $10^{20}$ & $\mathrm{Pas}$ & Scaling viscosity \\
\hline \multicolumn{4}{|c|}{ Temperature-dependent rheology } \\
\hline E & 120 & $\mathrm{~kJ} \mathrm{~mol}^{-1}$ & Activation energy \\
\hline$A_{\text {ref }}$ & $1.129 \times 10^{-4}$ & & Normalizing factor \\
\hline \multicolumn{4}{|c|}{ Temperature and pressure-dependent rheology } \\
\hline$E$ & $387^{\star}$ & $\mathrm{kJ} \mathrm{mol}^{-1}$ & Activation energy \\
\hline$V$ & 25 & $\mathrm{~cm}^{3} \mathrm{~mol}^{-1}$ & Activation volume \\
\hline$A_{\text {ref }}$ & $7.784 \times 10^{-19}$ & & Normalizing factor \\
\hline \multicolumn{4}{|c|}{ Temperature, pressure, and stress-dependent rheology } \\
\hline$E$ & 523 & $\mathrm{~kJ} \mathrm{~mol}^{-1}$ & Activation energy \\
\hline$V$ & 4 & $\mathrm{~cm}^{3} \mathrm{~mol}^{-1}$ & Activation volume \\
\hline$n$ & 3.6 & & Stress exponent \\
\hline$A_{\text {ref }}$ & $8.640 \times 10^{-12}$ & & Normalizing factor \\
\hline
\end{tabular}

Table 1. Model Parameters and Assumed Values 
is the temperature difference, $T_{m}$ is the mantle potential temperature, $\beta$ is a coefficient which sets the magnitude of density changes due to melt depletion, and $F$ is the total amount of melt removed. For comparison with geochemical and petrological data on residual peridotite samples, we use a parameter, $X$, which represents a completely compatible tracer. Assuming that the melt and solid remain in equilibrium with each other, mass balance dictates that

$$
F=\left(\frac{X-1}{X}\right)
$$

The value of $X$ increases from 1 as melting progresses, which allows a simple parameterization. $\beta$ can be calculated from a reference state of melt depletion:

$$
\beta=\frac{\Delta \rho_{\text {ref }}}{\rho_{0} F_{\text {ref }}}=\frac{\Delta \rho_{\text {ref }}}{\rho_{0}} \frac{X_{\text {ref }}}{X_{\text {ref }}-1}
$$

We shall also consider isopycnic conditions such that $\Delta \rho=0$ at all depths for the initial temperature distribution, which sets the initial vertical profile of $\Delta \rho_{F}$ in the thick continental lithosphere. In all calculations, we assume that no further melting occurs as the ocean-continent transition region evolves. It is convenient to introduce a buoyancy number:

$$
B=-\frac{\Delta \rho_{F}}{\Delta \rho_{T}}
$$

such that $B=1$ for an isopycnic structure.

[11] Schutt and Lesher [2006] have emphasized that the effect of melt depletion on density depends on pressure due to changes in the mineral assemblages that are in thermodynamic equilibrium with melt. For $F=20 \%(X=1.25)$, they find density reductions of $0.42-1.14 \%$ for $1-7 \mathrm{GPa}$. From the melting of model fertile lherzolite compositions and estimates from natural rocks, complete clinopyroxene removal occurs at a total melt fraction of roughly $23 \%$, corresponding to a Mg\# 92 for the solid residue [Lee, 2003; Schutt and Lesher, 2006]. We take this as our reference state of melt depletion. For $\Delta \rho_{\text {ref }}=34 \mathrm{~kg} \mathrm{~m}^{-3}$, close to the estimate of Poudjom Djomani et al. [2001] for Proterozoic lithosphere, $\beta=0.044$. According to Lee [2003], the density reduction for $\mathrm{Mg \#}=92$ is $\Delta \rho_{\text {ref }}=43.2 \mathrm{~kg} \mathrm{~m}^{-3}$, or $1.29 \%$ for $\rho_{o}=3340 \mathrm{~kg} \mathrm{~m}^{-3}$. This reduction in density is slightly larger than that estimated for Proterozoic lithosphere by Poudjom Djomani et al. [2001] and similar to the calculations of continental lithosphere density by Schutt and Lesher [2006]. For this set of parameters, $\beta=0.056$. There is some uncertainty in the density change due to melt removal and we shall consider these two different values of $\beta$ in order to illustrate the impact of the intrinsic buoyancy contrast between continents and oceans.

[12] The intrinsic buoyancy contrast between continental and oceanic lithosphere and the width of the transition zone are defined in the initial conditions of the model. These are of a linear geotherm to the base of the lithosphere that then transitions to a constant temperature of $1315^{\circ} \mathrm{C}$ and of a linear decrease in melt depletion to pristine mantle (Figure 2). Oceanic lithosphere is initially thermally and compositionally $100 \mathrm{~km}$ thick and continental lithosphere is $200 \mathrm{~km}$ thick. The margin marks a linear transition in thickness over horizontal distances of $100 \mathrm{~km}$ (sections 3.1 ) or $400 \mathrm{~km}$ (section 3.5 and Figure 2).

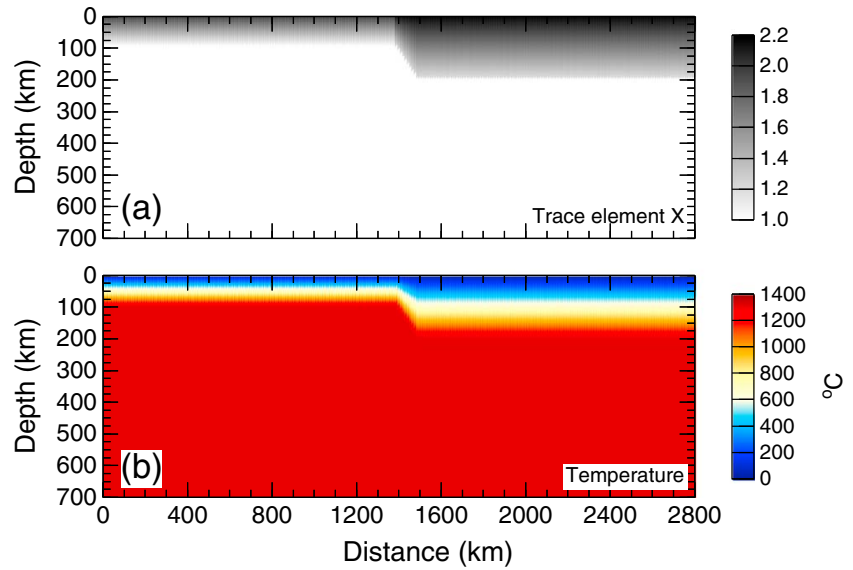

Figure 2. Initial condition for an "extra-depleted" continental lithosphere with a margin width of $100 \mathrm{~km}$. (a) Hypothetical trace element $X$ that is completely compatible. (b) Initial temperature within the model domain.

[13] For a given value of $\beta$, we introduce two intrinsic density structures, a "normal" and an "extra-depleted." The normal melt depletion case has an initial composition $X$ that increases linearly from bottom to top from $X=1$ to $X=2$ (Figures 2 and 3). Under this assumption, our normal continental lithosphere has a maximum melt removed at the surface of $50 \%$. For a base model, we take $\beta=0.044$, which gives a density that is greater than the isopycnic structure (Figure $3 \mathrm{~b}$ black line). The extra-depleted continental lithosphere has a melt depletion that is increased by $\Delta X=0.2$ from its base giving a melt removal of $16 \%$ at the base to $54 \%$ at the top (Figure 3 red line; see sections 3.1). This extra-depleted continental lithosphere has significant lower lithosphere buoyancy but becomes denser than isopycnic at shallow depths. We also consider two other intrinsic density structures: one with $\beta=0.056$ (Figure $3 \mathrm{c}$ thin lines), and a second where $\beta=0.087$ and the initial melt depletion is calculated such that $B=1$, an isopycnic initial condition. For the geotherm used here, $\Delta \rho_{F}=90 \mathrm{~kg} \mathrm{~m}^{-3}$ at the surface for this isopycnic initial condition. This density change is larger than that the average value for Archean lithosphere $\left(\sim 60 \mathrm{~kg} \mathrm{~m}^{-3}\right)$ [Poudjom Djomani et al., 2001].

\subsection{Time Scales of Flow and Lithosphere Rheology}

[14] In the absence of thermal convection, a buoyant continental lithosphere would thin and spread at the passive margin. Likewise the dense asthenosphere would flow laterally into and beneath the less dense continental lithosphere. At the same time, the lithospheric mantle can become convectively unstable which may affect the flow and surface topography. We now show that the two processes occur over comparable time scales, so that one cannot study one independently of the other.

[15] Assuming that the flow is isoviscous, the movement of the interface between continental and oceanic domains could be modeled simply a gravity current. For a fixed volume, the front of the gravity current varies with time to the power of a fifth $\left(t^{1 / 5}\right)$. Huppert [1982] derives the following solution for the movement of that front:

$$
L=C_{N}\left(\frac{\Delta \rho g A^{3}}{3 \eta_{l}}\right)^{1 / 5} t^{1 / 5}
$$


ARMITAGE ET AL.: INSTABILITY OF PASSIVE MARGINS
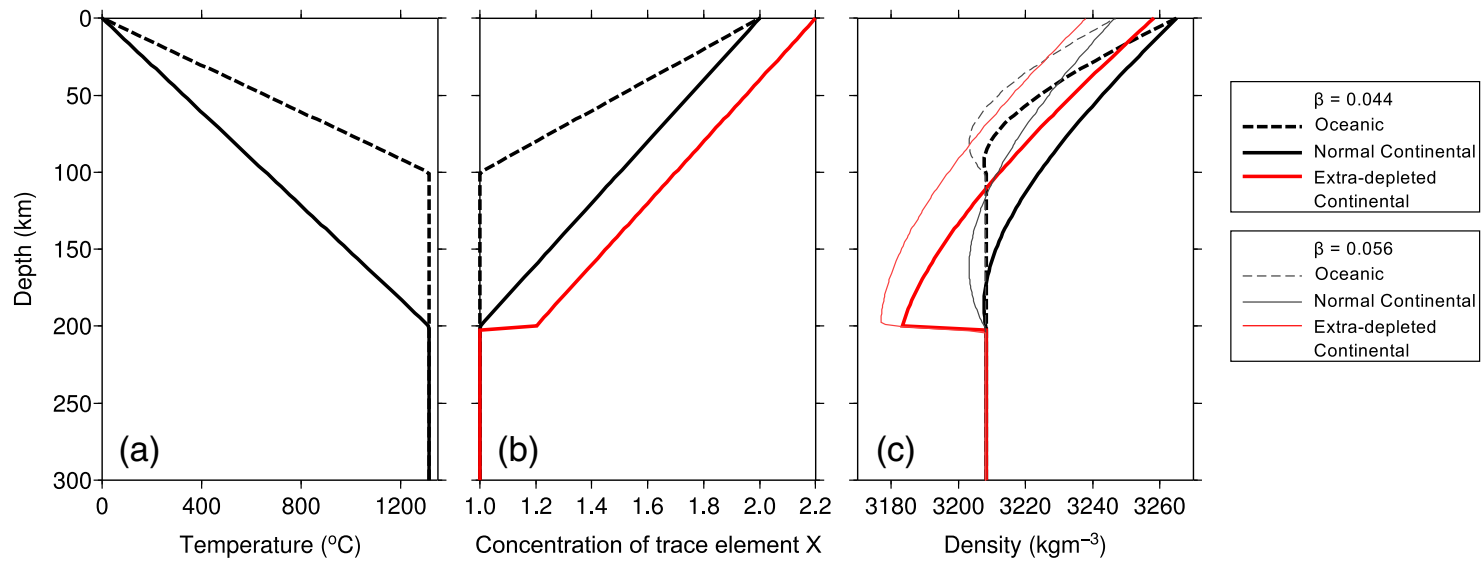

Figure 3. Initial conditions for the various model configurations. (a) Temperature and (b) hypothetical trace element, $X$, for the oceanic domain (dashed line) and continental domains (solid lines). In Figure 3b, the black solid line is for the normal continental lithosphere and the red solid line is for the extra-depleted continental lithosphere. (c) Density as a function of depth for $\beta=0.044$ (see equation (4)) compatible with the estimates of Poudjom Djomani et al. [2001] and Griffin et al. [2009], thick lines, and $\beta=0.056$ compatible with the estimate of Lee [2003], thin lines. For the larger value of $\beta$, the lower continental lithosphere becomes lighter than the asthenosphere for both the normal and extra-depleted conditions.

where $C_{N}=1.411 \ldots\left[\right.$ Pattle, 1959] and $g=9.81 \mathrm{~m} \mathrm{~s}^{-2}$ is the acceleration due to gravity. Assuming a bulk viscosity of $\eta_{l}=10^{20} \mathrm{~Pa}$ s and the 2-D area of continental lithosphere that spreads is fixed at $A=1400 \times 100 \mathrm{~km}$, for bulk density contrasts, $\Delta \rho$, of $10-40 \mathrm{~kg} \mathrm{~m}^{3}$, topographic changes due to the flow of the lithosphere and asthenosphere should migrate laterally by between 600 and $1000 \mathrm{~km}$ in $100-200 \mathrm{Myr}$ (Figure 4). For a lithosphere that has a bulk viscosity of $\eta_{l}=10^{22} \mathrm{~Pa} \mathrm{~s}$, lateral displacement of lower lithospheric material proceeds over distances between 200 and $400 \mathrm{~km}$ within the same time period (Figure 4).

[16] This lateral movement will most likely be altered by convection. Depending on the buoyancy of the continental lithosphere, it will either remain intact or destabilize by Rayleigh-Taylor-like instabilities into the asthenosphere below [Conrad and Molnar, 1997; Jaupart et al., 2007]. The pattern of instability is dependent on the buoyancy, parameterized by the buoyancy number, $B$, the thickness of the continental lithosphere, and the rheology. As the buoyancy number is increased beyond $B>0.5$, the continental lithosphere will likely stabilize to a state where the base oscillates but does not become entrained with the convecting asthenosphere below [Jaupart et al., 2007]. By making a linear approximation for the momentum and energy equation of the flow of an incompressible fluid, a critical dimensionless frequency, $\omega^{\prime}{ }_{c}$, and wave number for a thermally convecting two-fluid layered system of different densities can be calculated, from which the time scale of the development of instabilities can be estimated [Jaupart et al., 2007]:

$$
\mathcal{T}=\frac{2 \pi}{\omega^{\prime}} \frac{\eta_{l}}{\rho \alpha \Delta \operatorname{Tgh}}
$$

where for $B>0.3, \omega^{\prime}{ }_{c} \sim 50-150 \times 10^{-4} . \alpha=3.3 \times 10^{-5} \mathrm{~K}^{-1}$ is the coefficient of thermal expansion, $h=100-200 \mathrm{~km}$ is lithosphere thickness, and $\Delta T=1315^{\circ} \mathrm{C}$ is the temperature difference across the lithosphere. Using these values and assuming a bulk viscosity of $\eta_{l}=10^{20}-10^{22} \mathrm{~Pa} \mathrm{~s}$, the time scale for

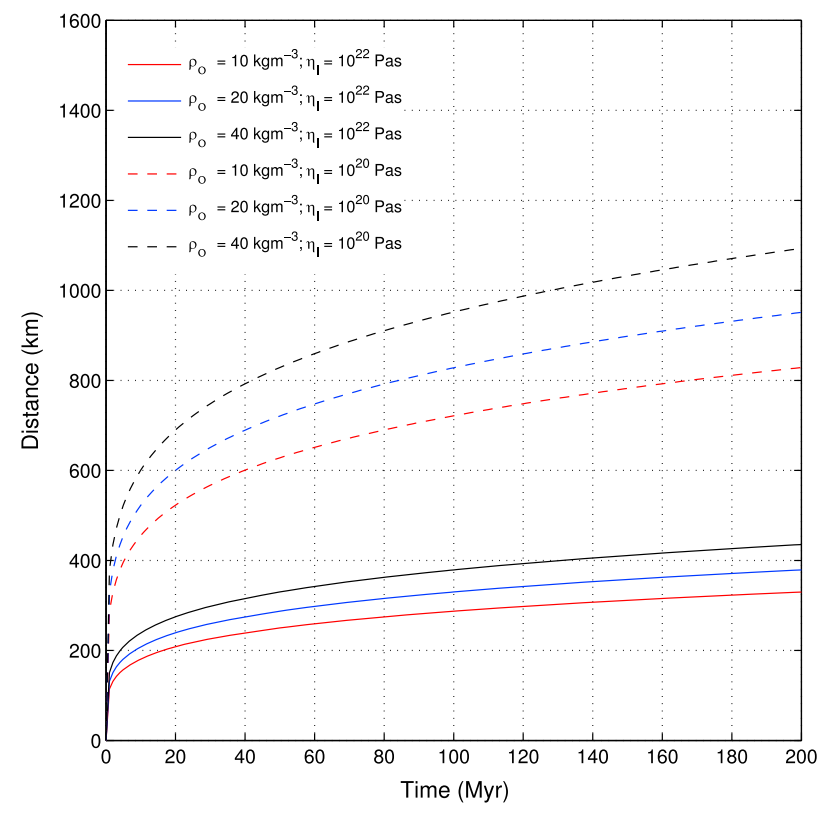

Figure 4. Position of the front of a gravity flow scaled to that of the model continental lithosphere, see equation (6).

instabilities to develop is between roughly $10 \mathrm{Myr}$ and $3 \mathrm{Gyr}$. The critical wave number has a value between 1.5 and 2 , giving a wavelength of three to four times the thickness of the lithosphere. For continental lithosphere of $200 \mathrm{~km}$ thickness, this gives a wavelength of 600 and $800 \mathrm{~km}$ [Jaupart et al., 2007].

[17] The time scales and length scales of the lateral and vertical motion of the continental lithosphere are therefore (1) of a similar order of magnitude, so in a thermally convecting system, it would be reasonable to assume that they would interact, and (2) dependent on the rheology of the convecting fluids. The response of the lithosphere to deglaciation suggests an upper mantle (asthenosphere and 


\section{ARMITAGE ET AL.: INSTABILITY OF PASSIVE MARGINS}

lithosphere) with a viscosity of the order of $10^{20}-10^{21} \mathrm{~Pa} \mathrm{~s}$ [Mitrovica and Forte, 1997]. This would potentially give a geologically rapid destabilization of the passive margin. However, the continental lithospheric mantle is likely to be more viscous than the asthenosphere [Hirth et al., 2000], implying a slower process.

[18] Laboratory experiments on olivine, which make up the bulk of the Earth's mantle, suggest that the mantle deforms by diffusion and dislocation creep [e.g., Weertman and Weertman, 1975; Goetze and Evans, 1979; Chopra and Paterson, 1984; Hirth and Kohlstedt, 1996; Mei and Kohlstedt, 2000]. The rheology differs if the solid mantle matrix is water-saturated, "wet," or water-poor, "dry" [Hirth and Kohlstedt, 1996; Mei and Kohlstedt, 2000]. The smallscale convection required to provide the observed heat flow beneath the Canadian shield furthermore suggest that the mantle more likely deforms by a "wet" dislocation creep mechanism [Lévy and Jaupart, 2011]. A recent reappraisal of experimental studies on the deformation of mantle rocks provides bounds for the activation energy, $E$, volume, $V$, and stress exponent, $n$, in the constitutive relationship between stress and strain-rate [Korenaga and Karato, 2008]. Before modeling the rheologies based on laboratory data, we first consider for simplicity a simple temperature-dependent diffusion creep that is a reasonable approximation for the deformation of the Earth based on geological observations (section 3.1) [Watts and Zhong, 2000]. In order to compare results obtained for different rheological laws, we impose a fixed viscosity value $\eta=10^{20} \mathrm{~Pa}$ s at $200 \mathrm{~km}$ depth.

[19] For temperature-dependent Newtonian material, viscosity is written as

$$
\eta=\eta_{0} A_{\text {ref }} \exp \left(\frac{E}{R T}\right)
$$

where $\eta_{0}=10^{20} \mathrm{~Pa} \mathrm{~s}$ and $A_{\text {ref }}=1.129 \times 10^{-4}\left(T_{\mathrm{ref}}=1588 \mathrm{~K}\right)$. Following Watts and Zhong [2000], we set the activation energy to $E=120 \mathrm{~kJ} \mathrm{~mol}^{-1}$, a small value which was determined empirically to achieve agreement between calculations of plate flexure near seamounts and observations. As shown by Christensen [1984], Jaupart and Mareschal [2011], and below, using such small activation energy may be regarded as a convenient expedient to approximate nonlinear dislocation creep by a Newtonian analog.

[20] It is most likely that the rheology of the Earth's interior is pressure dependent. Accordingly, we also consider a diffusion creep that is pressure and temperature dependent, taking the mean experimentally derived values for wet diffusion creep (section 3.2) [Korenaga and Karato, 2008],

$$
\eta=\eta_{0} A_{\text {ref }} \exp \left(\frac{E+p V}{R T}\right)
$$

where $E=387 \mathrm{~kJ} \mathrm{~mol}^{-1}, V=25 \mathrm{~cm}^{3} \mathrm{~mol}^{-1}$ [Korenaga and Karato, 2008], and $A_{\text {ref }}=7.784 \times 10^{-19}\left(T_{\text {ref }}=1588 \mathrm{~K}\right.$ and $\left.p_{\text {ref }}=6.55 \mathrm{GPa}\right)$.
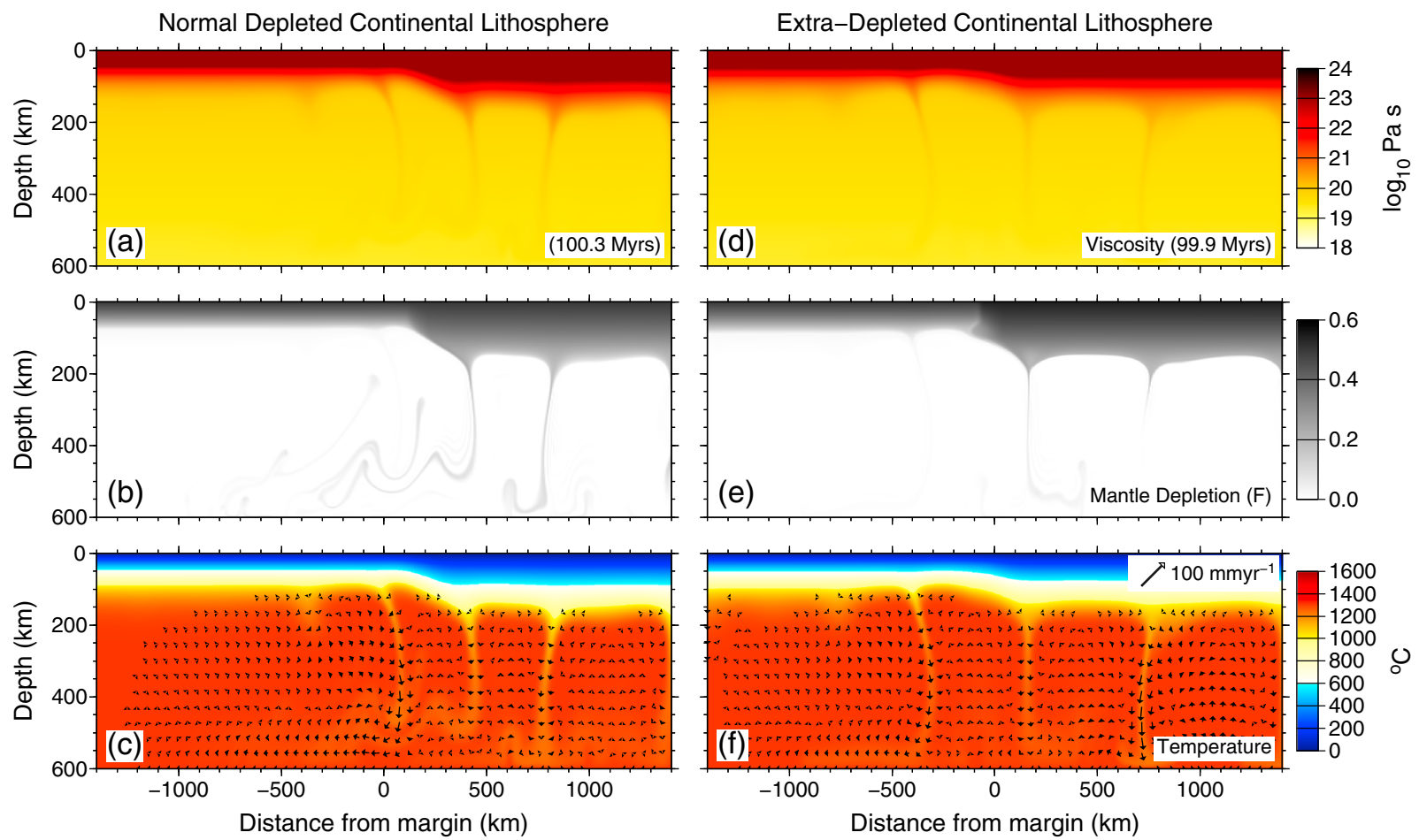

Figure 5. Upper mantle after $\sim 100 \mathrm{Myr}$ of model evolution for a temperature-dependent rheology where $\beta=0.044$ : (a) viscosity, (b) mantle depletion, $F$, and (c) temperature with vectors of flow, for a continental lithosphere that has a "normal" initial melt depletion that is linear from the base at $200 \mathrm{~km}$ to the surface from $F=0$ to 0.5 . (d) Viscosity, (e) mantle depletion, $F$, and (f) temperature with vectors of flow, for a continental lithosphere that has a "extra-depleted" initial melt depletion that is linear from the base at $200 \mathrm{~km}$ to the surface from $F=0.16$ to 0.54 . Inset top right is a vector of length $100 \mathrm{~mm} \mathrm{yr}^{-1}$ for scale. Model resolution is $512 \times 512$ elements. 
[21] Finally, the most likely mechanism of deformation within continental lithosphere is "wet" dislocation creep [Lévy and Jaupart, 2011]. Again taking the mean values from Korenaga and Karato [2008], we model the continental to oceanic lithosphere transition (section 3.3) assuming

$$
\eta=\eta_{0} A_{\text {ref }}^{1 / n} \exp \left(\frac{E+p V}{n R T}\right) I^{i^{\frac{1-n}{n}}}
$$

where $E=523 \mathrm{~kJ} \quad \mathrm{~mol}^{-1}, \quad V=4 \mathrm{~cm}^{3} \mathrm{~mol}^{-1}, \quad n=3.6$ [Korenaga and Karato, 2008], and $\dot{I}_{2}^{\prime}$ is the dimensionless second invariant of the deviatoric strain rate tensor. $A_{\text {ref }}=8.64 \times 10^{-12}$ for the reference state of $T_{\text {ref }}=1588 \mathrm{~K}$, $p_{\text {ref }}=6.55 \mathrm{GPa}$, and $\dot{\epsilon}_{\text {ref }}^{\prime}=\left(d^{2} / \kappa\right) \dot{\epsilon}_{\text {ref }}=490 \quad\left(\dot{\epsilon}_{\text {ref }}=\right.$ $\left.1 \times 10^{-15} s^{-1}\right)$. Note that the Arrhenius term in equation (10) involves an effective activation energy equal to $E / n$. This explains why the activation energy must be set at lower values in approximate Newtonian calculations of flow in nonlinear materials.

\subsection{Numerical Procedure}

[22] The equations of flow are solved over a $2800 \mathrm{~km}$ wide and $700 \mathrm{~km}$ deep 2-D domain with an aspect ratio of 4 to 1 using the convection code CitCom, with a viscosity cutoff of
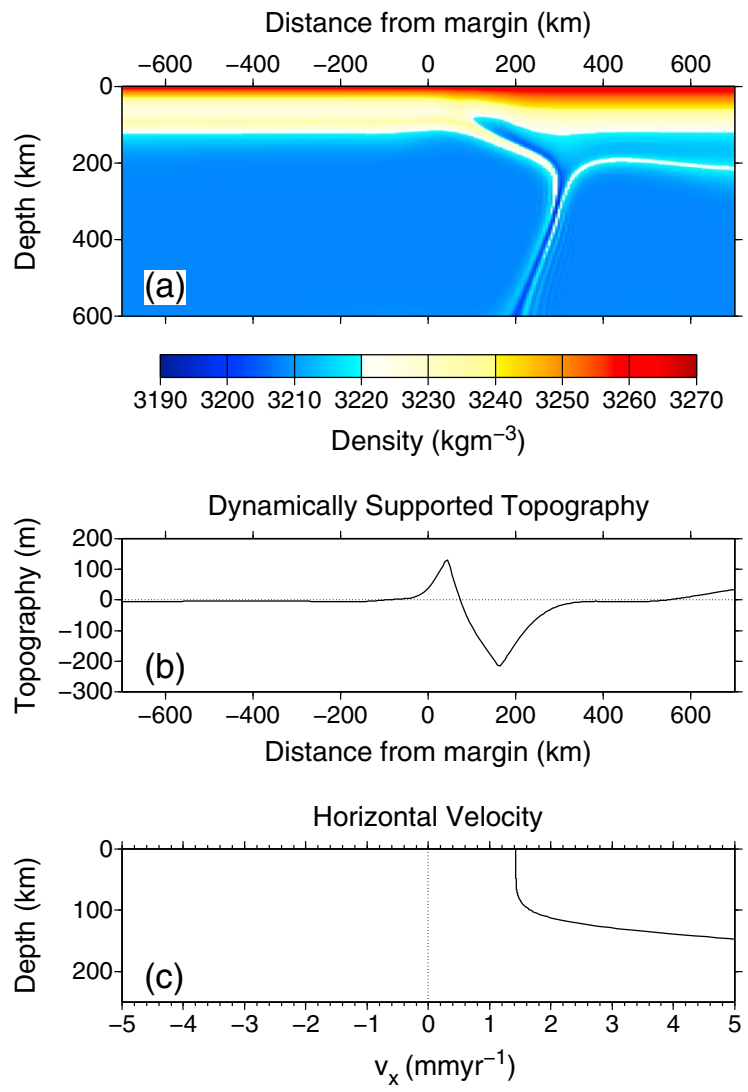

$10^{5}$ [Moresi et al., 1996; Nielsen and Hopper, 2004]. The model is based on CitCom version II by Louis Moresi, which was subsequently used to develop Ellipsus $3 D$. Boundary conditions are of free slip and of no normal flow. The velocity and pressure fields are solved using a multi-grid approach, with the temperature and melt depletion fields solved using a streamline upwing Petrov-Galerkin (SUPG) scheme [see Moresi and Solomatov, 1995]. Nonlinear viscosity is solved by repeated substitution at each multi-grid level of the Uzawa iteration [Moresi and Solomatov, 1998]. The SUPG leads to known overshoot, and to assess the impact of this on our results, we used Cartesian grids with different mesh sizes to verify that results were not sensitive to the numerical resolution. Grids with $256 \times 256,512 \times 512$, and $1024 \times 1024$ elements were explored, see Appendix A. We find that the surface topography supported by the normal stresses and the mantle heat flow is relatively unaffected by the resolution. We have used resolutions of $512 \times 512$ for the eight main models (sections 3.1 to 3.4 ). For the subsequent study of the isopycnic lithosphere and wide passive margin (sections 3.5 and 3.6), we used a resolution of $256 \times 256$ elements.

[23] The thermal Rayleigh number is set to $4.877 \times 10^{6}$ so that the scaling viscosity is $10^{20} \mathrm{~Pa} \mathrm{~s}$ :
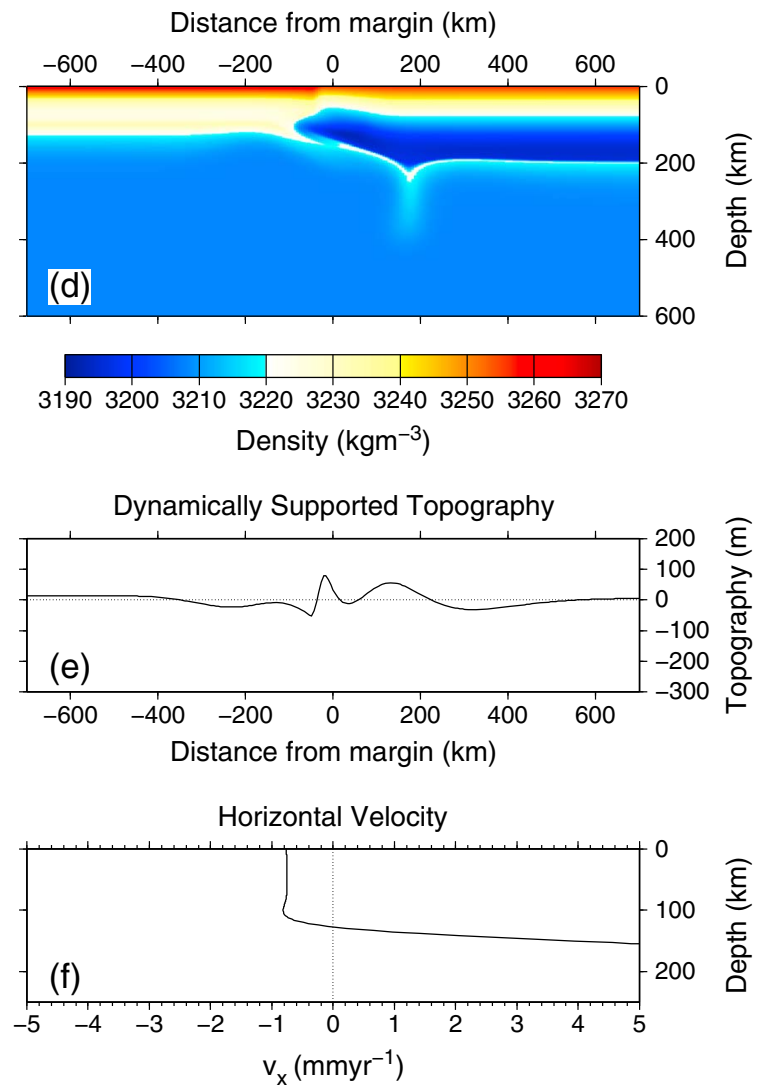

Figure 6. Margin structure for "normal" (left) and "extra-depleted" (right) continental lithosphere with a temperature dependent rheology at $\sim 50 \mathrm{Myr}$, where $\beta=0.044$. (a) Density at 56.0 Myr for continental lithosphere that is as depleted as the oceanic lithosphere at the surface, "normal" continental lithosphere. (b) Topographic change relative to the initial surface supported by the normal stresses. (c) Profile of horizontal velocity at $x=0 \mathrm{~km}$ in Figure 6a. (d) Density at $51.7 \mathrm{Myr}$ for continental lithosphere that is depleted by an extra $20 \%$, "extra-depleted" continental lithosphere. (e) Topographic change relative to the initial surface supported by the normal stresses. (f) Profile of horizontal velocity at $x=0 \mathrm{~km}$ in Figure 6c. Model resolution is $512 \times 512$ elements. 


$$
R a=\frac{\alpha g \rho_{m} \Delta T d^{3}}{\kappa \eta_{0}}=4.877 \times 10^{6}
$$

where $\alpha$ is the coefficient of thermal expansion, $g$ is the acceleration due to gravity, $d$ is the depth to the base of the model, $\kappa$ is the thermal diffusivity, and $\Delta T=1315^{\circ} \mathrm{C}$ is the superadiabatic temperature drop from the surface to depth $d=700 \mathrm{~km}$. For the physical properties of Table 1 and $R a=4.877 \times 10^{6}, \eta_{0}=10^{20} \mathrm{~Pa} \mathrm{~s}$.

[24] Topography changes induced by lithospheric and convective flows are expected to be small, typically a few hundred meters, which makes it possible to work with a fixed free surface. Uplift or subsidence is calculated from the normal stress balance at $z=0$ (Earth's surface):

$$
\prod_{z z}=\rho_{o} g h
$$

where $\Pi_{z z}$ is the normal stress and $h$ is elevation. To understand how topography may change as the model evolves, we then calculate the change in topography relative to the topography generated after the first time step.

\section{Results and Discussion}

[25] The rather simple system of a continental margin connecting thick depleted continental lithosphere to thinner oceanic lithosphere sets up three different types of flows. One is the gravity-driven horizontal flow of intrinsically buoyant continental material. Another is the convective circulation that is set up at the sloping edge of the thick continental root, which we shall call an edge flow. This flow is due to the lateral thermal contrast between well-mixed oceanic asthenosphere and strong continental lithosphere. A third type of flow is due to the convective breakdown of the unstable thermal boundary layers. These three flows interact in complex ways because they develop with different orientations to gravity and with different magnitudes depending on the host of parameters involved.

\subsection{Temperature Dependent Diffusion Creep}

[26] In this section, we consider the evolution of the continent to ocean transition for the temperature-dependent diffusion creep (equation (8)). The wavelength of convective instabilities is between 400 and $600 \mathrm{~km}$ for both the oceanic and thicker continental lithosphere, which is within the expected range from scaling arguments that convection cells will have a wavelength that is between three and four times the thickness of the lithosphere (Figure 5) [Jaupart et al., 2007]. Vigorous small-scale convection is not observed, which is due to the low activation energy. The largest dynamic feature in both the normal and extra-depleted continental lithosphere models is the edge flow set up by the change in lithosphere thickness with a maximum velocity of $50 \mathrm{~mm} \mathrm{yr}^{-1}$ (Figure 6). After $50 \mathrm{Myr}$ of model evolution, the margin has migrated by $\sim 60 \mathrm{~km}$ or at a rate of $\sim 1 \mathrm{~mm} \mathrm{yr}^{-1}$ toward the continent (Figures $6 \mathrm{a}$ and $6 \mathrm{c}$ ). This is reflected in the landward migration of the topographic low shown in Figure $6 \mathrm{~b}$ by $\sim 150 \mathrm{~km}$ in $100 \mathrm{Myr}$ (Figures $7 \mathrm{a}-7 \mathrm{c}$ ), as the convection cell migrates into the continental lithosphere (Figure 6a). The magnitude of horizontal lithospheric spreading is similar to that predicted
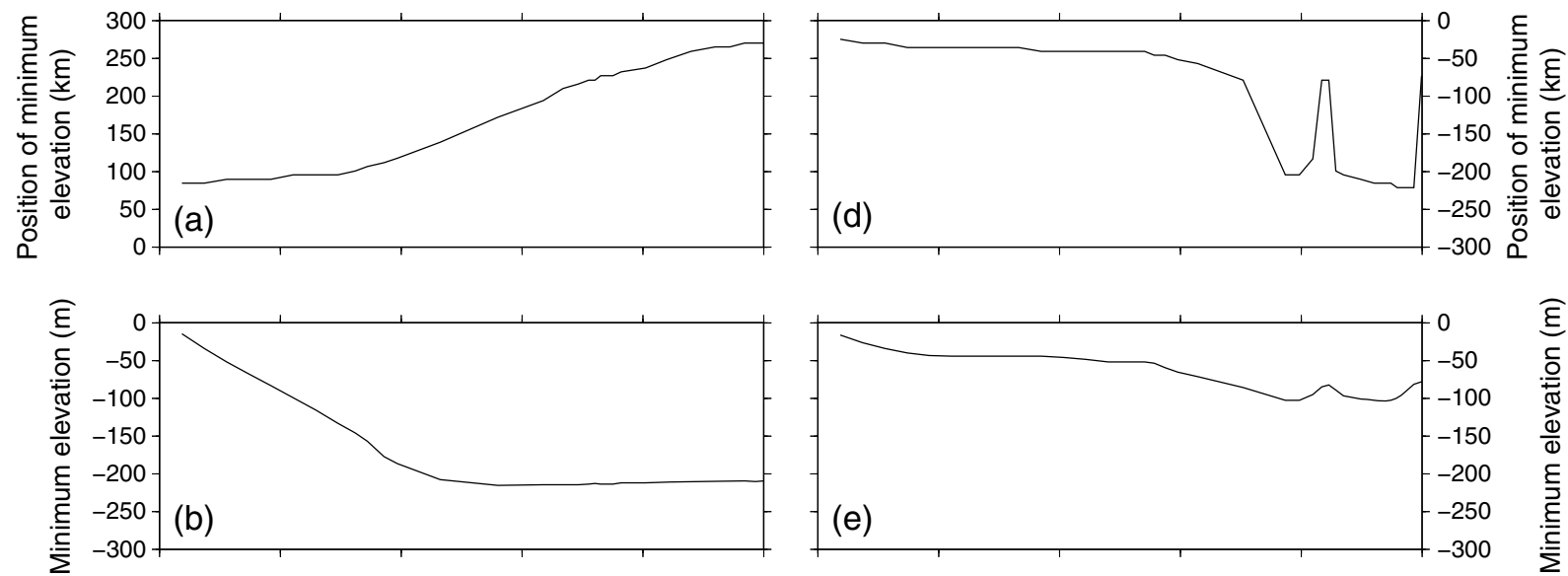

Figure 7. Movement of surface topography for a temperature dependent rheology. (a) The lateral position of the locus of minimum elevation relative to an $x$ coordinate of $0 \mathrm{~km}$, positive distance is landward, for the "normal" depleted continental lithosphere. (b) The elevation of the topographic low. (c) The elevation at a horizontal distance of $0 \mathrm{~km}$ within the model (Figures $6 \mathrm{a}$ and $6 \mathrm{c}$ ). ( $\mathrm{d}$ and e) As before but for the case of an "extra-depleted" continental lithosphere. 
from equation (6) for an isoviscous gravity current where the continental lithosphere has a viscosity of $10^{22} \mathrm{~Pa} \mathrm{~s}$ (Figure 4). These calculations illustrate how shallow lateral mantle density differences can drive topographic change and coastline migration at the passive margin.

[27] Migration of the coast, or the point of stratigraphic onlap in sedimentary sequences, is commonly observed during passive margin evolution, as observed for example at the eastern U.S., eastern Brazil, West Africa, and Western Australia. The New Jersey coastline, U.S., has moved $300 \mathrm{~km}$ landward in roughly $100 \mathrm{Myr}$. Coastline migration has been explained as due to a combination of flexure due to sediment loading and cooling of the lithosphere post breakup [e.g., Watts and Steckler, 1979; Bond and Kominz, 1984]. Onlap of sedimentary sequences at the passive margin may be generated by an increasing flexural rigidity [Watts, 1989]. Another possibility involves surface processes, such that a reduction in erosion rates as rift flanks are eroded back allows post breakup subsidence due to cooling to become the dominant mechanism [van Balen et al., 1995]. What these models neglect is mantle flow. From ocean bathymetry, it is clear that mantle convection affects subsidence after $80 \mathrm{Myr}$ of lithosphere evolution, and it is reasonable to assume that it will also influence subsidence at old passive margins. What we show is that subsidence at the coastline may be directly controlled by mantle flow.

[28] With enhanced depletion in the continental lithosphere (the "extra-depleted" case), a stronger lateral pressure gradient is set up at the ocean-continent transition. The buoyant continental lithosphere spreads into the oceanic
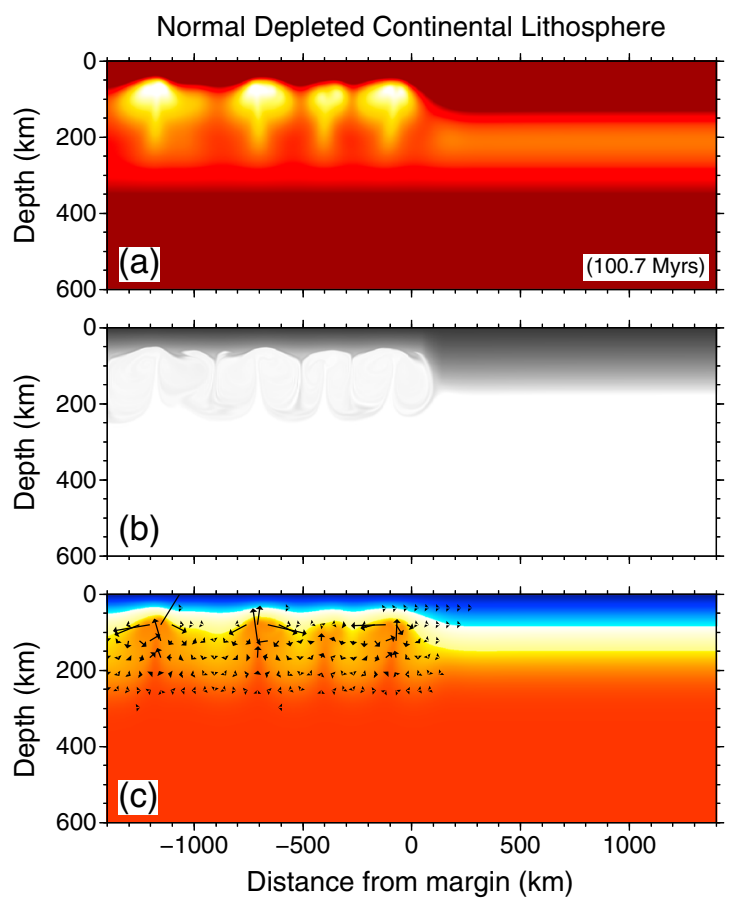

lithosphere, and the continental to oceanic transition moves toward the ocean at a rate of $\sim 1 \mathrm{~mm} \mathrm{yr}^{-1}$ (Figures $6 \mathrm{~d}$ and $6 \mathrm{f}$ ). This is reflected in the oceanward migration of the locus of minimum elevation and the subsequent high (100-150 m) elevation of the margin (Figures $7 \mathrm{~d}-7 \mathrm{f}$ ).

[29] We find that the effect of mantle flow on topography is very different for these two cases. (1) For normal continental lithosphere, the edge convective flow is dominant, generating a $200 \mathrm{~km}$ depression inboard of the margin that migrates landward (Figures 6b and 7a). (2) With extradepletion, the gravity spreading is dominant, resulting in an oceanward migration of topographic highs and deeper continental lithosphere, but it is hampered by the edge flow (Figures 6d, 6e, 7d, and 7f).

\subsection{Temperature and Pressure Dependent Diffusion Creep}

[30] In this section, we consider the evolution of the continent to ocean transition for the temperature and pressure dependent diffusion creep (equation (9)). Adding pressure dependence to the rheology has the effect of damping deeper convection as the viscosity at depth is higher (Figure 8). It has been previously suggested that this can help to explain the longevity of continental interiors [O'Neill et al., 2008]. After 50 Myr of margin evolution, the wavelength of instability is approximately $200 \mathrm{~km}$ beneath the old oceanic lithosphere (Figures 8 and 9). Small-scale convection leads to elevated topography within the ocean basin with ridges and troughs formed by the compression and extension of the upper lithosphere due to the convection cells (Figures 9b and 9e).
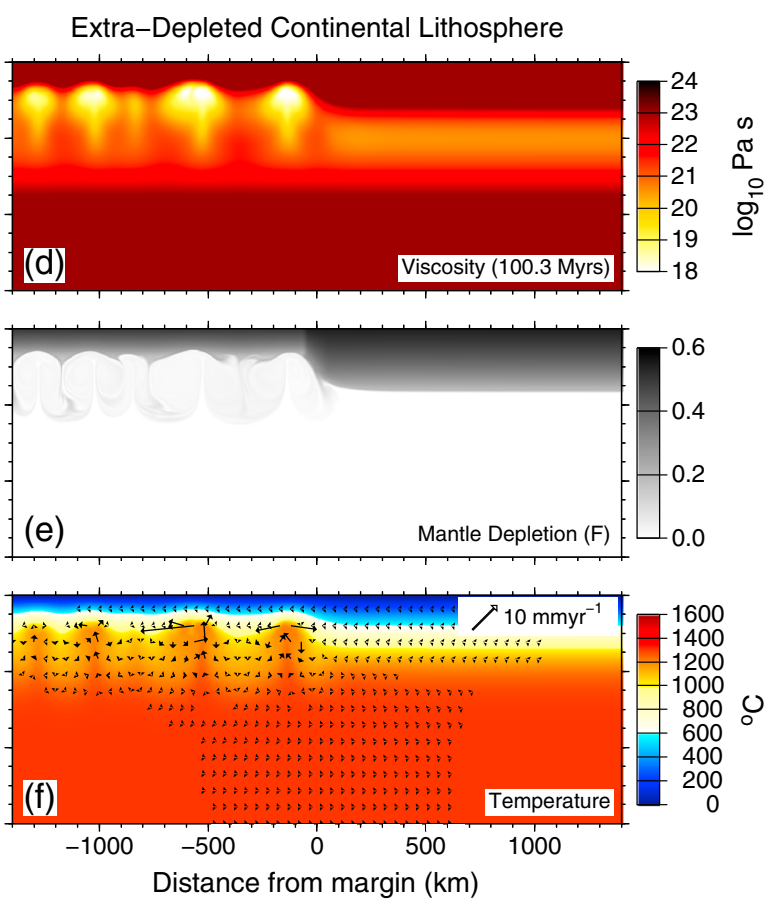

Figure 8. Upper mantle after $\sim 100 \mathrm{Myr}$ of model evolution for a temperature-pressure-dependent rheology where $\beta=0.044$ : (a) viscosity, (b) mantle depletion, $F$, and (c) temperature with vectors of flow, for a continental lithosphere that has a "normal" initial melt depletion that is linear from the base at $200 \mathrm{~km}$ to the surface from $F=0$ to 0.5 . (d) Viscosity, (e) mantle depletion, $F$, and (f) temperature with vectors of flow, for a continental lithosphere that has an "extra-depleted" initial melt depletion that is linear from the base at $200 \mathrm{~km}$ to the surface from $F=0.16$ to 0.54 . Inset top right is a vector of length $10 \mathrm{~mm} \mathrm{yr}^{-1}$ for scale. Model resolution is $512 \times 512$ elements. 

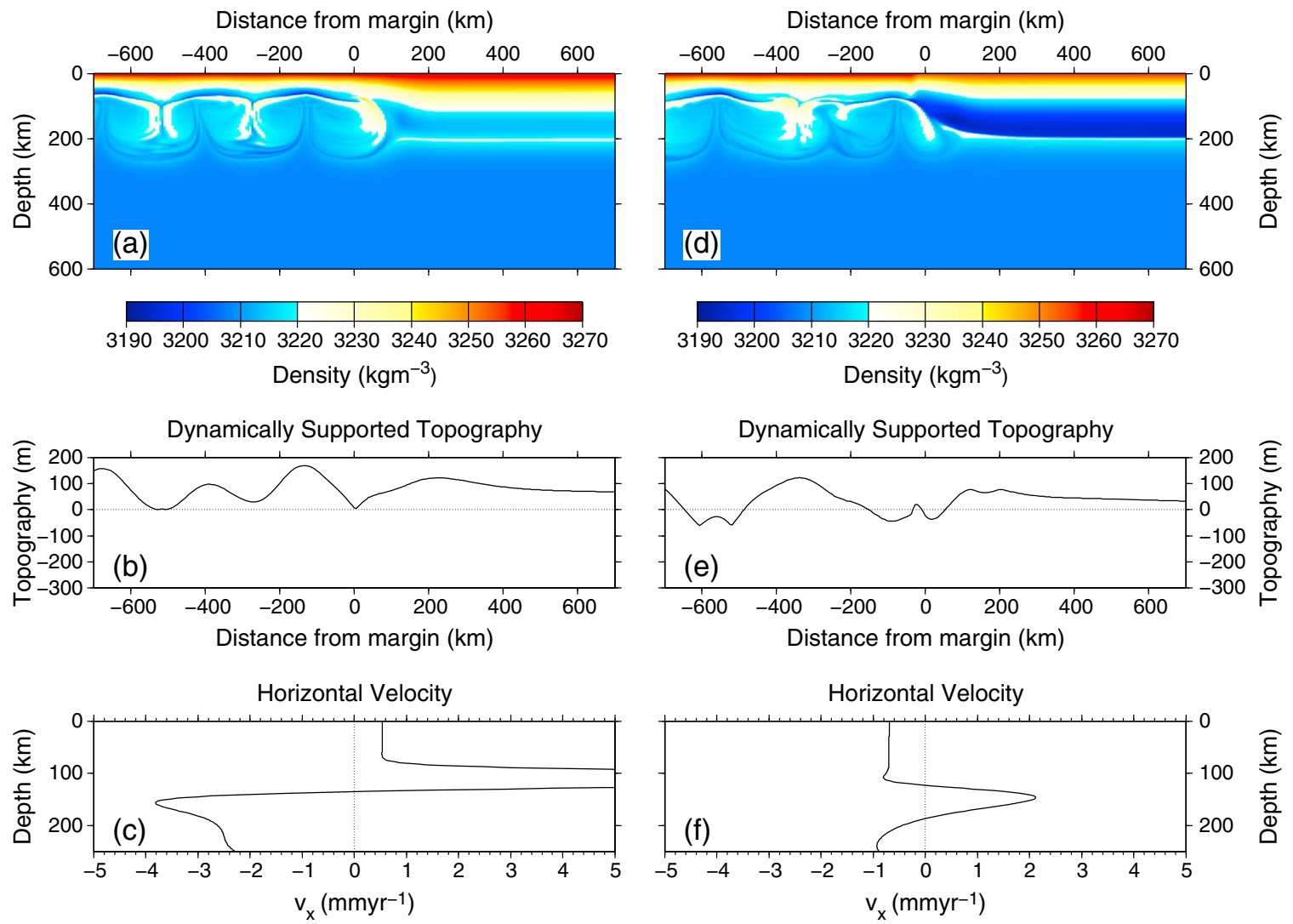

Figure 9. Margin structure for "normal" (left) and "extra-depleted" (right) continental lithosphere with a temperature-pressure-dependent rheology at $\sim 50 \mathrm{Myr}$, where $\beta=0.044$. (a) Density at $50.9 \mathrm{Myr}$ for continental lithosphere that is as depleted as the oceanic lithosphere at the surface, "normal" continental lithosphere. (b) Topographic change relative to the initial surface supported by the normal stresses. (c) Profile of horizontal velocity at $x=0 \mathrm{~km}$ in Figure 9a. (d) Density for continental lithosphere at $55.6 \mathrm{Myr}$ that is depleted by an extra $20 \%$, "extra-depleted" continental lithosphere. (e) Topographic change relative to the initial surface supported by the normal stresses. (f) Profile of horizontal velocity at $x=0 \mathrm{~km}$ in Figure 9c. Model resolution is $512 \times 512$ elements.

[31] With respect to the previous set of calculations, the bulk behavior of the margin is the same but there are significant differences in the flow of continental lithosphere. For continental lithosphere with normal melt depletion, the convection cell closest to the margin places the continent once more in compression (Figures 9a-9c). For an extra-depleted continent, the buoyancy once more causes the continental lithosphere to flow toward the oceanic domain causing margin migration (Figures 9d-9f). The two sets of calculations, which involve exactly the same physical properties and Rayleigh number save for lithosphere buoyancy, predict different characteristics for the small-scale convection cells that develop in the oceanic domain. The pair of convection cells closest to the margin has a wavelength that is roughly $100 \mathrm{~km}$ wider for the case of the continental lithosphere with normal melt depletion, which has a knock-on effect on the more distal cells, as can be seen in Figures 8c, 8f, 9a, and 9c. These differences are due to the contrasting lateral lithospheric flows that develop. In these two cases, these flows differ not only in their absolute velocities but also in their direction.

[32] With temperature-pressure-dependent diffusion creep, the continent is stable for $200 \mathrm{Myr}$. The pressure dependence increases the strength of the deeper regions of the lithosphere such that convection is limited to the upper $300 \mathrm{~km}$
(Figures 8,9a, and 9b). The effect is to produce regions of uplift and subsidence with a wavelength of $200-300 \mathrm{~km}$ in the oceanic domain. A similar mantle flow pattern has been found by Shahnas and Pysklywec [2004] and Ramsay and Pysklywec [2011], who linked this to the high topography of Bermuda Rise in the western Atlantic Ocean. In our calculations, however, the margin migrates, which affects the dimensions and velocity of convection cells. For the more buoyant continental lithosphere, the oceanward migration reduces the velocity of the upward return flow and narrows horizontal aspect of the convection cell (compare Figures 9a and 9b with 9d and 9e). In the earlier studies of Shahnas and Pysklywec [2004] and Ramsay and Pysklywec [2011], the rheology is temperature dependent only, with a high viscosity imposed within the continental lithosphere, such that it is essentially fixed and nondeformable. With the pressure dependence on the rheology, one also generates strengthening of the deeper continental lithosphere which prevents destabilization of the lithosphere.

\subsection{Temperature and Pressure-Dependent Dislocation Creep}

[33] In this section, we consider the evolution of the continent to ocean transition for the temperature and pressure dependent dislocation creep (equation (10)). Due to the shear- 
thinning behavior, once a convection cell is initiated, the viscosity reduces and flow can intensify (Figures 10 and 11). This overcomes the strengthening of the deep lithosphere due to pressure dependence and a flow pattern similar to the temperature-dependent rheology is recovered (see Figures 5 and 10). For continental lithosphere that has not been extensively melt-depleted, "normal," the result is relatively steady landward migration of topographic lows and density anomalies at a speed of close to $1 \mathrm{~mm} \mathrm{yr}^{-1}$ (Figures 12a, and 12b, and 11a). The subsequent interaction between the lateral movement of the transition region and convective instabilities causes an episodic rise and fall of topography at a fixed position at the surface (Figure 11c).

[34] For normal-depleted continental lithosphere, there is enough lithospheric flow to put the continental lithosphere into compression, where after $50 \mathrm{Myr}$ of model evolution, the continent-oceanic lithosphere transition has migrated by $\sim 60 \mathrm{~km}$ landward (Figure 12a). Movement of the lithosphere transition zone, from continental to oceanic, for the extra-depleted case is oceanward at a rate of $1 \mathrm{~mm} \mathrm{yr}^{-1}$ (Figures 11d and 11f), but the effect on margin topography is not as strong as for the normal case (compare Figures 12a$12 \mathrm{c}$ with $12 \mathrm{~d}-12 \mathrm{f}$ ). The minimum in topography remains relatively fixed at $-50 \mathrm{~m}$ at a distance of between 50 and $150 \mathrm{~km}$ oceanward of the initial transition zone, $0 \mathrm{~km}$ (Figures 11d, 12d-12f).

[35] The degree of lithosphere erosion or movement of the continent to oceanic lithosphere transition zone has been discussed previously. An early model found that an initially sharp continent-ocean transition gets smeared out and becomes rounded [Shapiro et al., 1999], in contrast to our present results. The key difference is that we allow for horizontal movement at the upper surface boundary with a freeslip condition, while in the numerical models of Shapiro et al. [1999] the upper surface is fixed. In more recent numerical models, Hardebol et al. [2012] have argued in favor of very efficient continental lithosphere erosion, of up to $1000 \mathrm{~km}$ in $100 \mathrm{Myr}$. There is little evidence for flow of this magnitude at a continental margin, and we certainly do not reproduce it here. We attribute the difference to the fact that Hardebol et al. [2012] do not allow for an intrinsically buoyant continental lithosphere. When density change due to melt depletion is included along with the effects of pressure on lithosphere rheology, which strengthens the deeper mantle, the convective vigor is reduced along with the amount of continental lithosphere erosion. It is possible that the passive margin can be used as a rheometer and, to a degree, a density meter for the lithosphere. How it deforms is a function of these two parameters, where coastline migration and changes in elevation can provide useful bounds on the lithosphere structure.

\subsection{The Effect of Increased Buoyancy}

[36] Models of the melting of mantle rocks suggest that the density difference of the residual solid matrix after $23 \%$ melt removal compared to the mantle might be greater than that estimated for the Proterozoic lithosphere: $43.2 \mathrm{~kg} \mathrm{~m}^{-3}$ compared to $32 \mathrm{~kg} \mathrm{~m}^{-3}$ [Poudjom Djomani et al., 2001; Lee, 2003; Griffin et al., 2009]. The effect of changing $\beta$ from 0.044 to 0.056 to account for this possible larger density
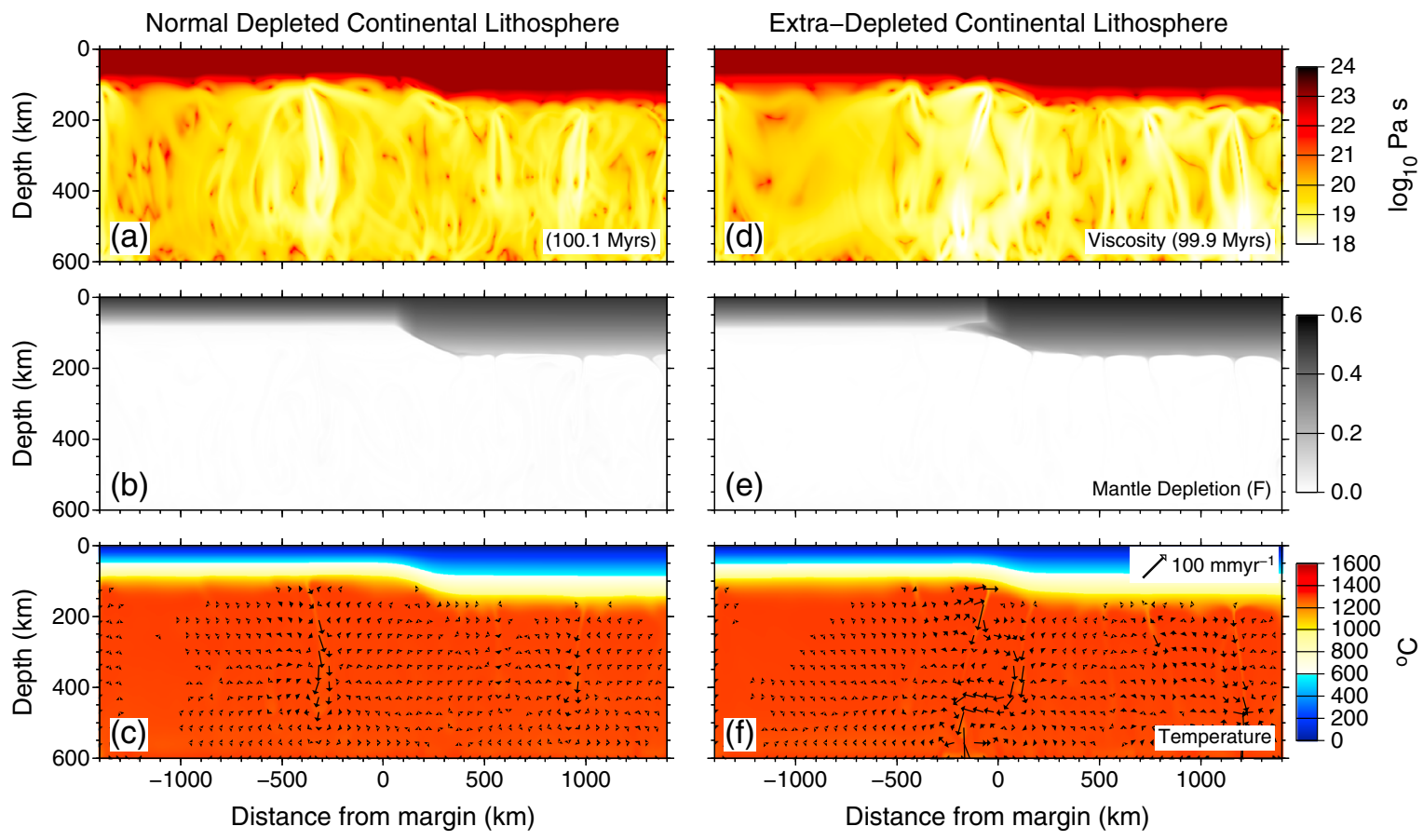

Figure 10. Upper mantle after $\sim 100 \mathrm{Myr}$ of model evolution for a temperature-pressure-stress-dependent rheology where $\beta=0.044$ : (a) viscosity, (b) mantle depletion, $F$, and (c) temperature with vectors of flow, for a continental lithosphere that has a "normal" initial melt depletion that is linear from the base at $200 \mathrm{~km}$ to the surface from $F=0$ to 0.5 . (d) Viscosity, (e) mantle depletion, $F$, and (f) temperature with vectors of flow, for a continental lithosphere that has a "extra-depleted" initial melt depletion that is linear from the base at $200 \mathrm{~km}$ to the surface from $F=0.16$ to 0.54 . Inset top right is a vector of length $100 \mathrm{~mm} \mathrm{yr}^{-1}$ for scale. Model resolution is $512 \times 512$ elements. 

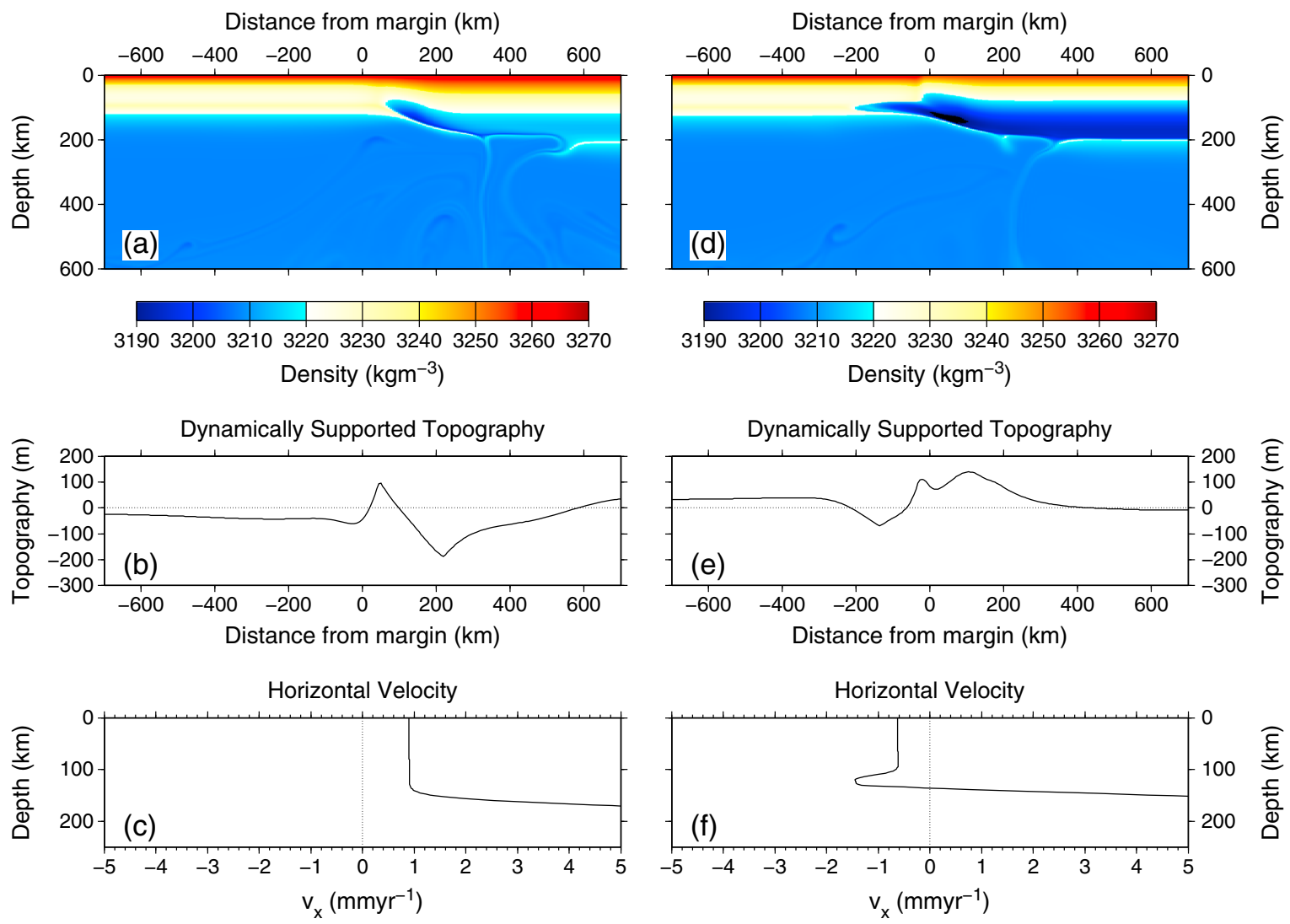

Figure 11. Margin structure for "normal" (left) and "extra-depleted" (right) continental lithosphere with a temperature-pressure-stress-dependent rheology at $\sim 50 \mathrm{Myr}$, where $\beta=0.044$. (a) Density at $50.0 \mathrm{Myr}$ for continental lithosphere that is as depleted as the oceanic lithosphere at the surface, "normal" continental lithosphere. (b) Topographic change relative to the initial surface supported by the normal stresses. (c) Profile of horizontal velocity at $x=0 \mathrm{~km}$ in Figure $11 \mathrm{a}$. (d) Density at 50.1 Myr for continental lithosphere that is depleted by an extra 20\%, "extra-depleted" continental lithosphere. (e) Topographic change relative to the initial surface supported by the normal stresses (f) Profile of horizontal velocity at $x=0 \mathrm{~km}$ in Figure $11 \mathrm{c}$. Model resolution is $512 \times 512$ elements.

contrast is to make the whole lithosphere much more buoyant and stable. In the case of a temperature and pressure-dependent dislocation creep (equation (10)), the convective instability at the base of the lithosphere is much reduced (Figures $13 \mathrm{a}$ and $13 \mathrm{~d})$. The edge-driven flow generates a wisp of material that destabilizes into the asthenosphere for both cases of melt depletion. For the case where the continental lithosphere is not significantly depleted, this greater stability is displayed in the lack of significant change in topography (Figure 13b). Furthermore, due to the increased buoyancy of both the oceanic and continental domains, the lateral drift of the transition zone is, after $50 \mathrm{Myr}$, small. The horizontal velocities within the lithosphere are less than $0.5 \mathrm{~mm} \mathrm{yr}^{-1}$ (Figure 13c). Increasing $\beta$ has made the oceanic and lower regions of the continental lithosphere lighter than the mantle (Figure 3c); therefore until the convective thermal boundary layer has developed beneath the oceanic lithosphere, the asthenosphere beneath the oceanic lithosphere is denser than the cooler continental lithosphere, driving oceanward lateral spreading. As the thermal boundary layer grows, the continental lithosphere becomes denser than the adjacent oceanic asthenosphere, leading to a shift in the direction of lateral spreading. In the case where the continental lithosphere is extra-depleted, it is always less dense than the oceanic lithosphere and asthenosphere. The transition zone maintains a high topography because the margin is in compression as buoyant continental lithosphere spreads oceanward at a velocity of $\sim 1 \mathrm{~mm} \mathrm{yr}^{-1}$ (Figures $13 \mathrm{e}$ and 13f).

[37] This case (normal melt depletion with $\beta=0.056$ ) is the most stable scenario, with minimal horizontal movement of the continent to ocean transition zone and a high degree of stability against convective breakdown. This is due to the lower continental and oceanic lithospheres being both lighter than the underlying asthenosphere. This model, however, is difficult to reconcile with the lack of free air gravity and geoid anomalies within the continents, and with the chemistry of cratonic mantle xenoliths. These xenoliths typically have $\mathrm{Mg \#}$ that is too large, such that they are denser than isopycnic (although there is a lot of spread within the data; e.g., Lee et al. [2011]).

\subsection{Isopycnic Lithosphere}

[38] For the isopycnic initial condition, where both the oceanic and continental lithosphere has changes in density due to melt depletion that are exactly balanced by thermally induced ones, we only discuss results for temperature and pressure-dependent dislocation creep (equation (10)). We find that there is greater vertical stability against convective breakdown than in the previous models (compare Figures 10 and 14), as expected. Horizontal stability, however, is not 

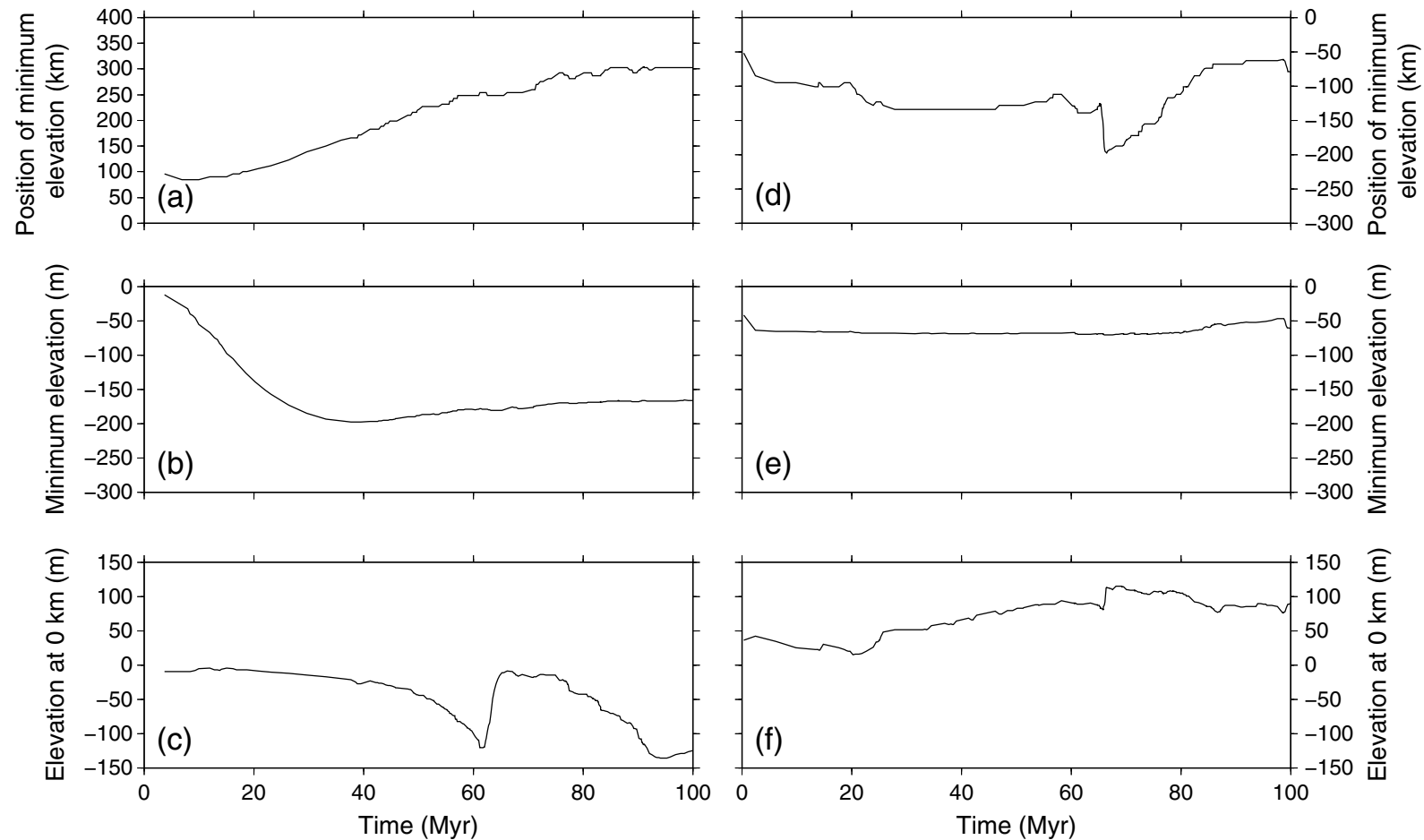

Figure 12. Movement of surface topography for a temperature-pressure-stress-dependent rheology. (a) The lateral position of the locus of minimum elevation relative to an $x$ coordinate of $0 \mathrm{~km}$, positive distance is landward, for the "normal" depleted continental lithosphere. (b) The elevation of the topographic low. (c) The elevation at a horizontal distance of $0 \mathrm{~km}$ within the model (Figures 11a and 11c). (d and e) As before but for the case of an "extra-depleted" continental lithosphere.

maintained. The oceanic lithosphere cools more rapidly than the continental lithosphere due to the greater change in temperature with depth (Figure 15). This destroys the initial isopycnic structure and a lateral density contrast develops at the margin, with continental lithosphere that is more buoyant than the adjacent oceanic lithosphere. The continental to oceanic transition migrates into the ocean by a distance of the order of $100 \mathrm{~km}$ in $100 \mathrm{Myr}\left(1 \mathrm{~mm} \mathrm{yr}^{-1}\right)$. This is reflected in the topography, which migrates oceanward by roughly $100 \mathrm{~km}$.

\subsection{Margin Width}

[39] Up until now we have considered models where the margin initially thickens from ocean to continent over a width of $100 \mathrm{~km}$. Such a width is typical of many rift margins, including the volcanic southeast Greenland margin [Holbrook et al., 2001; Hopper et al., 2003] and its conjugate, the Hatton Bank [Fowler et al., 1989]. Just to the south of Hatton Bank, however, the margin is much wider and reaches $400 \mathrm{~km}$ [Vogt et al., 1998]. Likewise, offshore Uruguay, the margin is spread over more than $300 \mathrm{~km}$ [Chang et al., 1992]. To explore the effect of a wider continent to ocean transition, we have modeled a $400 \mathrm{~km}$ wide transition region for both depletion cases with $\beta=0.044$ (Figure 16).

[40] In the case of a temperature and pressure-dependent dislocation creep (equation (10)), increasing the margin width has the effect of reducing the strength of the edge flow (Figures 16a and 16c). This results in, (1) for the normal depletion case, a more stable margin that does not migrate landward to a high degree and, (2) for the extra-depleted case, the edge flow that could resist the lateral flow of buoyant continental lithosphere is diminished, and the continent-ocean transition rapidly migrates oceanward, reaching a distance of close to $200 \mathrm{~km}$ from its initial position after $50 \mathrm{Myr}$. This is reflected in the broad region of $50 \mathrm{~m}$ high topography that stretches out oceanward (Figure 16b).

\subsection{Discussion of Modeling Assumptions}

[41] Our calculations were made for a specific set of physical properties and mantle rheological parameters chosen within ranges allowed by current experimental constraints. We have explored the impact of lithospheric buoyancy and have illustrated a wide range of possible behaviors. All flows are driven by buoyancy, which acts in predictable ways and directions. The effect of changing the values for the coefficient of thermal expansion or for the initial temperature distributions can be understood easily using the buoyancy number $B$. As shown by equation (6), changing the reference viscosity value $\eta_{0}$ has a weak effect on the spreading velocity and hence on the characteristic times for margin evolution.

[42] The calculations were made in 2-D and hence cannot account for the heterogeneity of real geological structures. We note, however, that the characteristics of continental margins seem to be rather uniform over large distances along strike, which is consistent with 2-D behavior. A 3-D model would require specification of along-strike variations of lithosphere composition and structure as well as of the style 

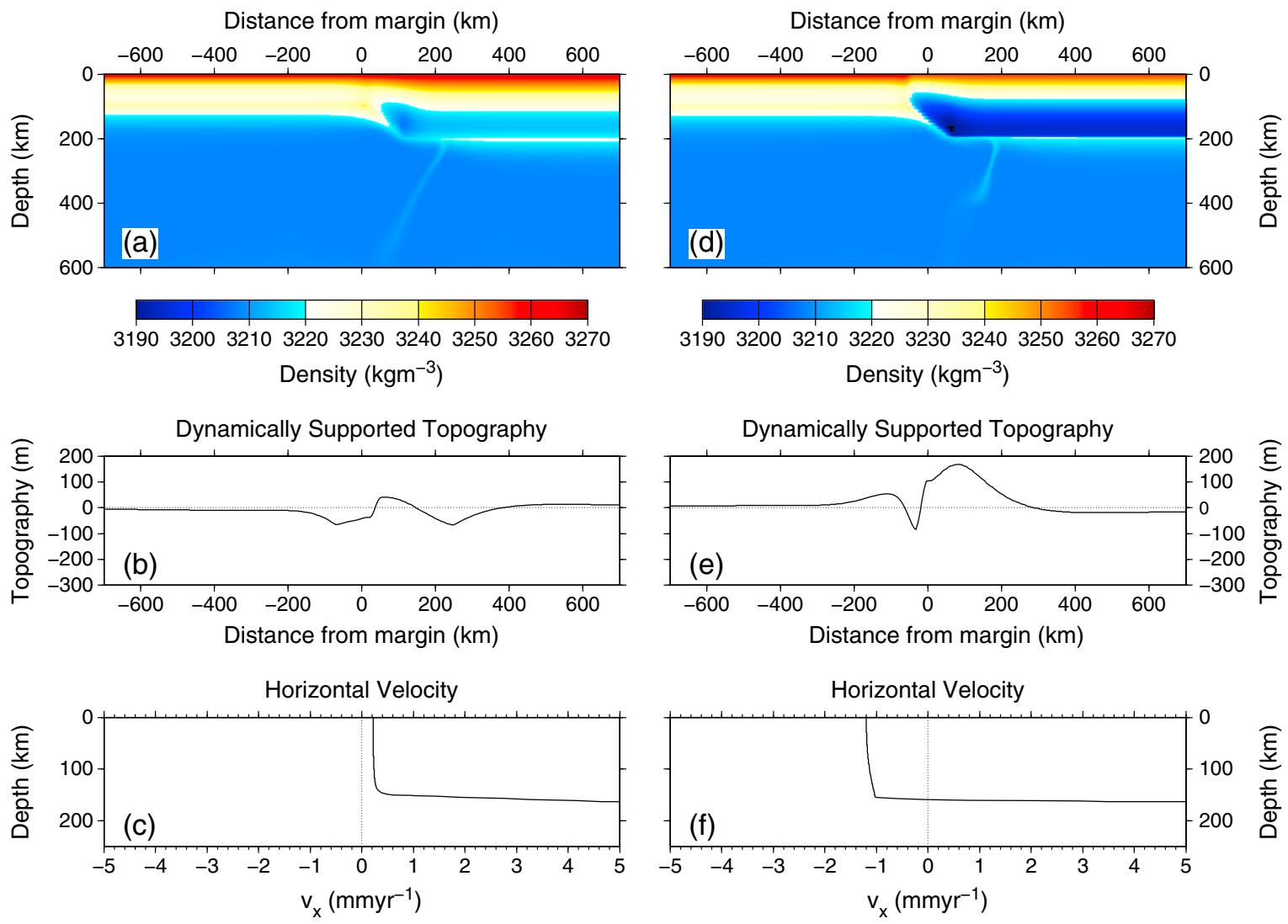

Figure 13. Margin structure for "normal" (left) and "extra-depleted" (right) continental lithosphere with a temperature-pressure-stress-dependent rheology at $\sim 50 \mathrm{Myr}$, where $\beta=0.056$. (a) Density at $55.5 \mathrm{Myr}$ for continental lithosphere that is as depleted as the oceanic lithosphere at the surface, "normal" continental lithosphere, and vectors of flow. (b) Topographic change relative to the initial surface supported by the normal stresses. (c) Profile of horizontal velocity at $x=0 \mathrm{~km}$ in Figure 13a. (d) Density at $53.4 \mathrm{Myr}$ for continental lithosphere that is depleted by an extra $20 \%$, "extra-depleted" continental lithosphere. (e) Topographic change relative to the initial surface supported by the normal stresses. (f) Profile of horizontal velocity at $x=0 \mathrm{~km}$ in Figure $13 \mathrm{c}$. Model resolution is $512 \times 512$ elements.

of rifting with consequences for the initial margin configuration. Such information is rarely available with the degree of precision that is needed and we felt that this should be left for future investigations where the rather complex behavior shown here would serve as a useful starting point.

\section{Implications of Lateral Lithospheric Flow at Continental Margins}

[43] The set of numerical model results presented here confirms that continental lithosphere that is highly depleted has great stability against convective breakdown (Figure 14), as proposed by Jordan [1981]. For a continent of finite size that lies adjacent to ocean basins, however, this is not sufficient to guarantee total stability, as the intrinsic buoyancy of the lithospheric mantle induces spreading in the horizontal direction (e.g., Figures $11 \mathrm{~b}$ and 11c). Thus, enhancing stability against convective breakdown may be regarded as self-defeating in a sense because it also enhances lateral destabilization. We find that flow of lithosphere at the margin causes topographic lows and highs that migrate either oceanward or landward with differing velocities. We discuss the possible implications of these results below.

\subsection{Continent Subsidence and Coastline Migration}

[44] The North American eastern margin has undergone a history of periodic increases in subsidence and a general landward migration of the coastline since its formation in the Late Jurassic (Figure 17) [Heller et al., 1982]. The relative sea level changes on the eastern coast of North America since the Eocene have been attributed to mantle flow related to descent of the Farallon slab [Moucha et al., 2008; Spasojevic et al., 2008]. This dynamic topographic signal is not found on the opposite side of the central north Atlantic on the West African margin [Moucha et al., 2008]. Subduction of oceanic lithosphere can cause wide scale subsidence of the continental interior [Coakley and Gurnis, 1995; Burgess et al., 1997]. The North West European margins have also experienced periods of uplift and subsidence continuously since the Eocene [Stoker et al., 2010]. Stresses from remote tectonic events can, in theory, cause increased subsidence within extensional and flexural basins [Karner, 1985]. Compressional regimes have also been invoked for 

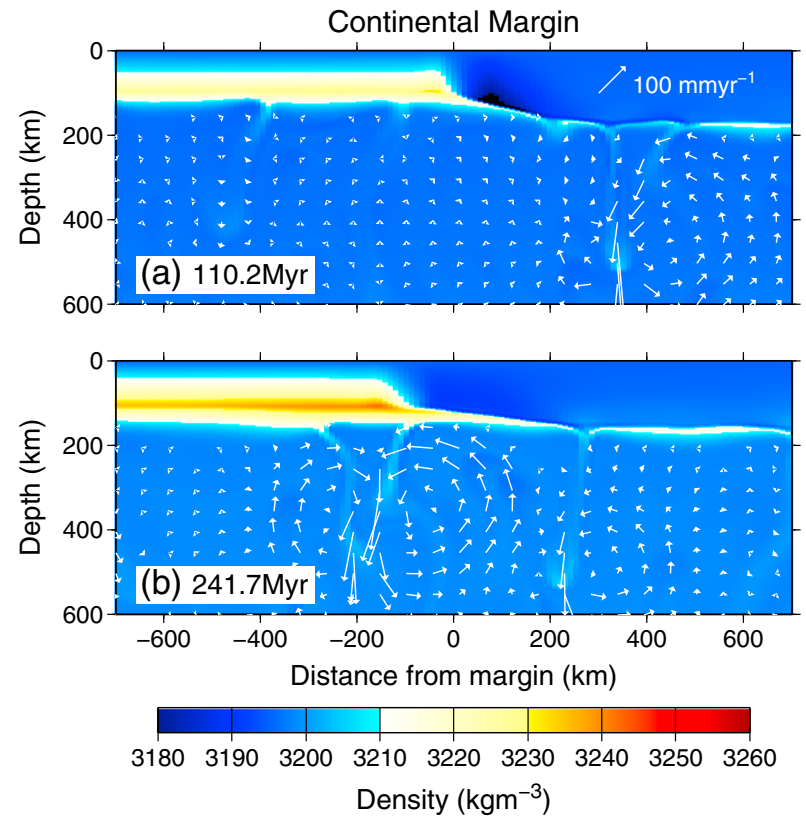

Dynamically Supported Topography

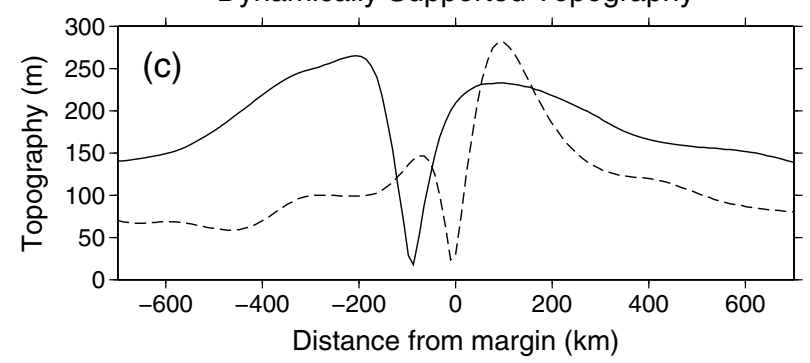

Figure 14. Density structure for the isopycnic initial condition, where $\beta=0.087$ and the initial melt depletion, $F$, is calculated to balance the thermal contribution (a buoyancy number of $B=1$ ). (a) Density at the margin after $110.2 \mathrm{Myr}$. Inset top right is a vector of length $100 \mathrm{~mm} \mathrm{yr}^{-1}$ for scale. (b) Density at the margin after 241.7 Myr. (c) Topography across the margin, dashed line at 110.2 Myr and solid line at 241 Myr. Model resolution is $256 \times 256$ elements.

the formation of interior basins [Shaw et al., 1991] and large-scale continental uplift [Hillis et al., 2008]. We argue, however, that the large forces that are generated within the continental passive margin itself, driven by changes in thermal and compositional structure, will continually change margin topography (Figures 7 and 12). There are two styles:

[45] 1. If the continental lithosphere is not highly depleted, there is initially a general tilting of the margin toward the ocean (Figures 6c and 11c), followed by alternating uplift and subsidence of the margin (Figures 7c, 12c, and 17b) and landward migration of the coastline.

[46] 2. If the continental lithosphere is highly depleted, there are margin uplift (Figures $6 \mathrm{~d}$ and 11d) and migration of the continent to ocean transition zone toward the ocean (Figures 6f and 11f).

[47] The continental platform of North America is most likely associated with weak compositional buoyancy because of its relatively young age. The initial regional tilting toward the ocean found in our simulations has similarities
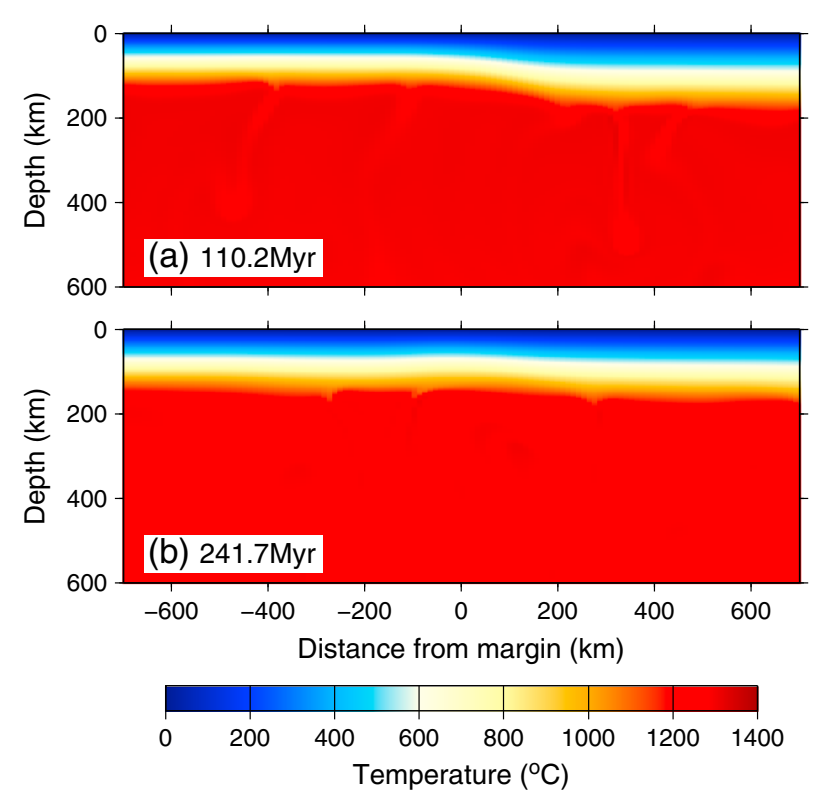

Figure 15. Temperature field for the isopycnic initial condition, (a) after 110.2 Myr and (b) after 241.7 Myr. Model resolution is $256 \times 256$ elements.

with the regional tilting observed during the Sauk super sequence of North America (Figure 1a) [Sloss, 1988; Burgess, 2008] and the earliest sedimentary sequences of north Africa [Selley, 1972; Boote et al., 1998]. In the U.S., the Sauk sequence outlines a region of broad tilting that extends roughly $2000 \mathrm{~km}$ inland of the continent to ocean transition, and the stratigraphic units progressively onlap into the continent [Burgess, 2008]. In our idealized 2-D model, we find a region of tilting that extends into the continent over a distance of $400 \mathrm{~km}$ due to convective erosion of the continental lithosphere. Our model is 2-D while the Earth evolves in 3-D, and during the latest Proterozoic to Early Ordovician, the North American eastern margin had two landward striking rift zones that may have extended this tilting deeper into the continent due to the associated thinning of the lithosphere. In addition, the continental lithosphere may have been in a phase of general extensional stress associated with continental breakup, which may have added to the regional tilting [Armitage and Allen, 2010]. Importantly, longwavelength tilting occurred before subduction of the Iapetus in the Middle Ordovician [Coakley and Gurnis, 1995], suggesting that the initial tilting of the passive margin was not due to subduction and was due instead to breakup and associated processes.

[48] As well as tilting of the continent at the then young passive margin, continents that are not highly buoyant in nature are more likely to experience landward migration of the continent-ocean transition and the topographic consequences of this are dynamically supported subsidence and uplift that are episodic. We find that coastline migration is due to the lateral spreading of deep lithospheric mantle as thermally driven convection cells erode into the thicker continental lithosphere. Although erosion and deposition will feedback into the evolution of a margin, it is crucial to question whether coastline migration is a consequence of lateral mantle flow or of changes in flexural loading as time progresses. 

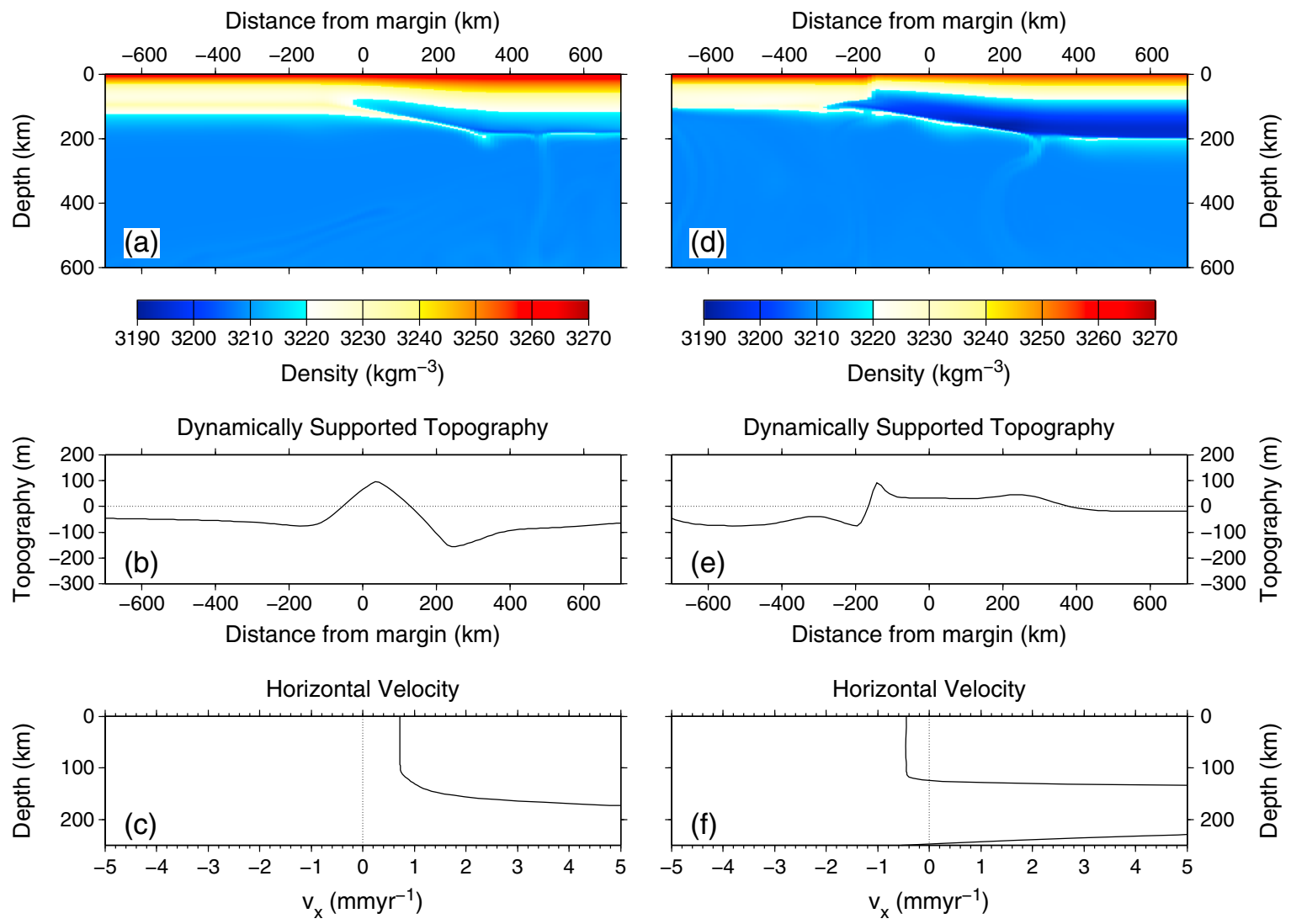

Figure 16. Margin structure for "normal" (left) and "extra-depleted" (right) continental lithosphere with $400 \mathrm{~km}$ margin width and a temperature-pressure dependent rheology at $\sim 50 \mathrm{Myr}$, where $\beta=0.044$. (a) Density at 52.1 Myr for continental lithosphere that is as depleted as the oceanic lithosphere at the surface, "normal" continental lithosphere. (b) Topographic change relative to the initial surface supported by the normal stresses. (c) Profile of horizontal velocity at $x=0 \mathrm{~km}$ in Figure 16a. (d) Density at $53.5 \mathrm{Myr}$ for continental lithosphere that is depleted by an extra $20 \%$, "extra-depleted" continental lithosphere. (e) Topographic change relative to the initial surface supported by the normal stresses. (f) Profile of horizontal velocity at $x=0 \mathrm{~km}$ in Figure $16 \mathrm{c}$. Model resolution is $256 \times 256$ elements.

[49] Intracratonic basins and continental platform subsidence of North America show periods of subsidence and uplift superimposed on a slow, very long term background trend (Figures 1 and 17) [Heller et al., 1982; Armitage and Allen, 2010; Allen and Armitage, 2012]. Taking two borehole subsidence curves from the eastern North American margin, the magnitude of change in topography is similar to that produced by destabilization of the lithosphere at the margin (100-200 m; Figures $17 \mathrm{~b}$ and 17c). Similar pulses of uplift/subsidence superimposed on a long-term background trend are found in the West Siberian Basin, Russia (Figure 1b), the interior basins of South America [Soares et al., 1978; Nikishin et al., 2002; Saunders et al., 2005], and Australia [Lindsay et al., 1987; Shaw et al., 1991; Lindsay, 2002]. We suggest that these are due to the intrinsic instability of the continent-ocean transition region. Other consequences are changes in the stress field at the surface, similar to those predicted by Forte et al. [2007], which could be the root cause of the many earthquakes observed at passive margins.

\subsection{Continental Passive Margin Heat Flow}

[50] It is often considered that older continental regions have a greater compositional buoyancy than younger ones
[Sleep, 2005] and that this may explain the highly eroded surface of northern Canada. From our 2-D numerical models, we have found that increased lithosphere buoyancy leads to oceanward continental flow at margins, with a spreading rate that is dependent on the initial lithospheric geometry.

[51] Heat flow signatures at passive margins might provide insight into the flow of deeper continental lithosphere. The isopycnic continent and extra-depleted continent have lower heat flow at the margin compared to continental lithosphere with normal depletion (Figure 18). This is because for the latter, the edge flow erodes into the continental margin reducing lithosphere thickness and insulation of the mantle. Heat flow in Voisey Bay, Labrador, North America, has a mantle contribution of $<15 \mathrm{~mW} \mathrm{~m}^{-2}$ [Mareschal et al., 2000]. Voisey Bay sits at the coastline of eastern Canada. Offshore heat flow measurements indicate that, away from the margin, the mantle contribution to heat flow is much higher and similar to oceanic values [Goutorbe et al., 2007]. That the transition from continental to oceanic heat flow signatures exists right at the margin is in agreement with our model predictions (Figure 18, red and blue lines). Furthermore, the gravitational flow of buoyant 

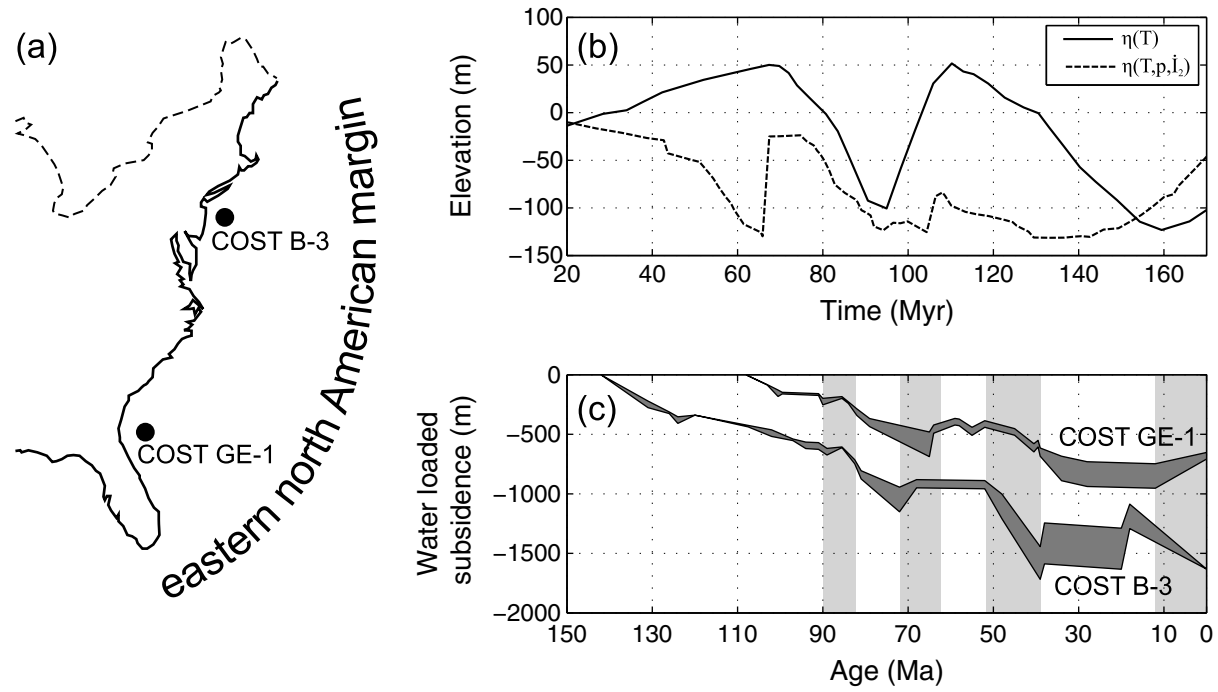

Figure 17. Eastern North American margin subsidence and change in margin elevation predicted from the numerical model. (a) Map of the margin with the location of the two bore holes. (b) Predicted change in elevation for the temperature dependent diffusion creep rheology with $\beta=0.044$ and "normal" melt depletion in the continental lithosphere (section 3.1; solid line), and the temperature and pressure-dependent dislocation creep rheology (section 3.3; dashed line). (c) Back-stripped water loaded minimum and maximum subsidence curves for the two bore holes COST GE-1 and COST B-3, from Heller et al. [1982].

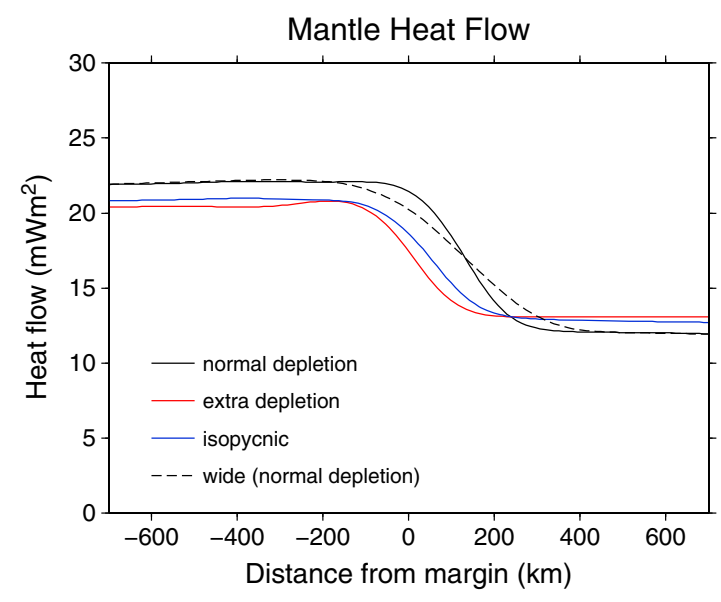

Figure 18. Mantle heat flow after $100 \mathrm{Myr}$ of model evolution for three non-Newtonian model cases: "normal" depleted, "extra-depleted" $(\beta=0.044)$, and isopycnic continental lithosphere $(\beta=0.087)$.

continental lithosphere would help to explain why the Labrador Sea is anomalously shallow [Louden et al., 2004].

[52] To the south of the Labrador Sea, the Newfoundland margin and its conjugate, the Iberian margin, are both very wide. If margin width is some function of breakup processes, then for wide margins, we expect a reduced heat flow signature from the mantle extending out into the shelf seas (Figure 18, dashed line). This reduction is due to the reduced vigor of convection driven by the transition in lithosphere thickness. Encouragingly, lower than average heat flow values are measured across the wide Goban Spur and Galicia Bank [Louden et al., 1991].

[53] Other margins have observations of high heat flow and volcanism that could be related to mantle flow such as the young Gulf of Aden passive margin [Lucazeau et al., 2008] and the older southeast Australian passive margin [Sandiford and Egholm, 2008; Holfard et al., 2011]. At both these margins, it has been suggested that high heat flow values are due to upper mantle flow at the edge of thick continental lithosphere. We have shown that under the right density contrasts such a flow is to be expected, although we do not observe a significant return flow of the upper mantle to generate any melt due to decompression, even when we include a deep "wet" solidus [e.g., Armitage et al., 2008]. To achieve vigorous edge flow that generates melt would likely require the whole system to be migrating above the deeper mantle, creating a "mantle wind" [King and Anderson, 1998].

\section{Conclusions}

[54] Continental lithosphere is thicker and more meltdepleted than its oceanic counterpart. Melt depletion leads to a compositional buoyancy that helps to stabilize the lithosphere from sinking into the asthenosphere below. A possible case is that continental lithosphere is isopycnic, where density variations due to temperature are perfectly offset by a compositional change. But such an ideal cannot hold where thin lithosphere undergoes a transition to thick, due to the cooling of the lithosphere bringing about lateral contrasts in density. Lateral changes in density lead to large forces and horizontal movement of the upper mantle. This horizontal flow can be opposed by thermally driven circulation that nucleates off the strong thickness gradient between the oceanic and continental lithosphere. How these two flows interact has large implications on the evolution of passive margins and adjacent continental interiors. 

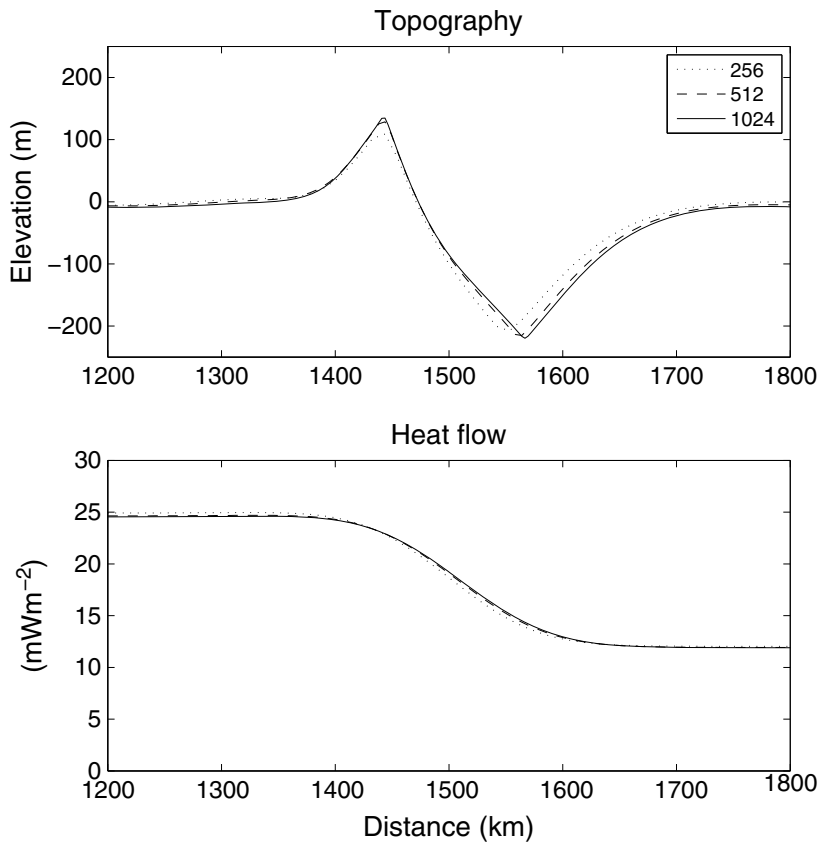

Figure A1. Topography and heat flow for the temperature dependent rheology after $50 \mathrm{Myr}$ for resolutions of $256 \times 256,512 \times 512$, and $1024 \times 1024$ elements. (a) Topography change relative to the initial topography supported by the normal stresses. (b) Heat flow at the surface of the model. It can be seen that the difference in topography and heat flow for these three different model resolutions is only very minor.

[55] In model runs, highly melt-depleted continental lithosphere flows laterally into the oceanic lithosphere, potentially reducing the surface heat flow at the coast. The flow of buoyant lithosphere would also maintain a high topography that migrates out into the ocean basin. This is a possible explanation for the high elevation of the Labrador Sea seafloor. The lateral flow of lithosphere is relatively indifferent to lithosphere rheology, but convection is sensitive to the activation volume of the upper mantle. For increasing pressure dependence, larger convection cells do not form, limiting small-scale convection to beneath the oceanic lithosphere. From a purely physical standpoint, these calculations show that one must account for the pressure dependence of the rheology in geological contexts involving lithospheres of different thicknesses.

[56] The geological record particularly from North America and also from North Africa shows that after their formation, passive margins experience a broad ramp-like tilting toward the ocean. Subsidence is subsequently episodic in nature with a landward migration of the coastline. Periods of uplift and subsidence can be related to a number of individual events. However, the very nature of the transition in lithosphere thickness and density nucleates instabilities in the continental lithosphere. If the compositional buoyancy of the continental lithosphere is low, these instabilities generate first a ramp-like tilting of the continental interior, followed by episodic periods of increased subsidence as convective cells roll away from the margin landward. Consequently, episodes of uplift and increased subsidence are to be expected in continental interiors and adjacent passive margins due to the natural thermomechanical evolution of the margin.

\section{Appendix A: Numerical Resolution}

[57] We wished to assess the accuracy of calculating the change in topography from the normal stresses for increased model resolution. We have tested all three rheologies with grid resolutions of $256 \times 256,512 \times 512$, and $1024 \times 1024$ elements. The reason for this is the SUPG solvers used to advect the melt depletion are known to overshoot and cause a front to develop ahead of the field that is being advected. The resulting change in topography supported by the normal stresses and the surface heat flow after 50 Myr of model evolution is shown in Figure A1 for the temperature-dependent diffusion creep (equation (8)). For this snapshot in time for all model resolutions, there is very little difference in topography or heat flow. The evolution of the dynamic topography is essentially identical for all three resolutions (Figure A2). The same is true for the temperature and pressure-dependent diffusion creep and dislocation creep. This numerical error is reduced by increasing the resolution and there exist simple filters for reducing this numerical error [e.g., Lenardic and Kaula, 1993], yet given that the topography and heat flow are relatively indifferent to this error, for our purposes adding an additional filter is not necessary. In the models presented in the main body of this paper, we have used a resolution of $512 \times 512$ and $256 \times 256$.

(a)

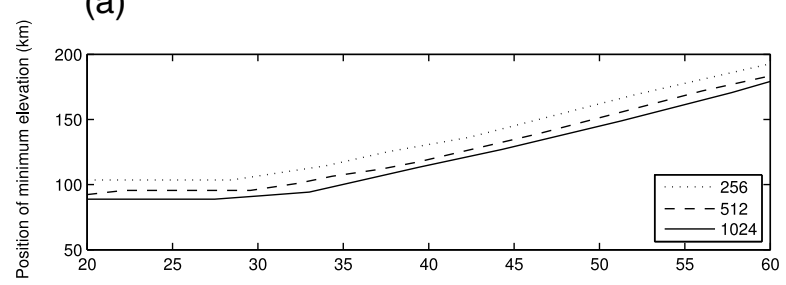

(b)

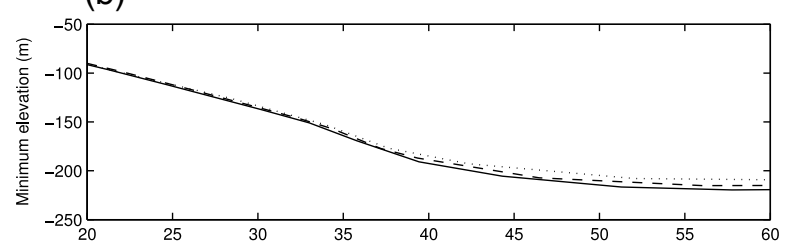

(c)

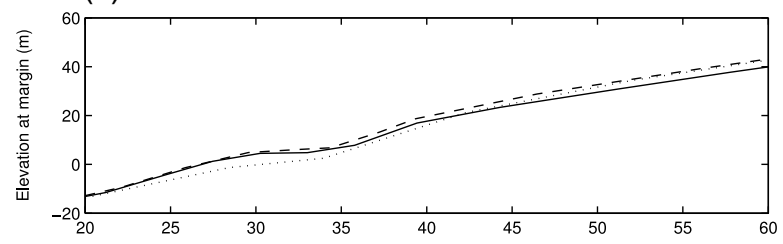

Figure A2. Movement of surface topography for a temperature dependent rheology for resolutions of $256 \times 256$, $512 \times 512$, and $1024 \times 1024$ elements. (a) The lateral position of the locus of minimum elevation relative to an $x$ coordinate of $0 \mathrm{~km}$, positive distance islandward, for the "normal" depleted continental lithosphere. (b) The elevation of the topographic low. (c) The elevation at a horizontal distance of $0 \mathrm{~km}$ (Figure 6). 
[58] Acknowledgments. The authors would like to thank Laura Alisic and the second anonymous reviewer. This work was funded by a Marie Curie Fellowship to John Armitage (project 272669). This is IPGP contribution 3356.

\section{References}

Afonso, J. C., G. Ranalli, and M. Fernández (2007), Density structure and buoyancy of the oceanic lithosphere revisited, Geophys. Res. Lett., 34, L10302, doi:10.1029/2007GL029515.

Allen, P. A., and J. J. Armitage (2012), Cratonic basins, in Syntectonic Basin Development, Active to Ancient: Recent Advances, edited by C. Busby, and A. Azor, chap. 30, pp. 602-620, Wiley-Blackwell, Oxford. Armitage, J. J., and P. A. Allen (2010), Cratonic basins and the long-term subsidence history of continental interiors, J. Geol. Soc. Lond., 167, 61-70, doi:10.1144/0016-76492009-108.

Armitage, J. J., T. J. Henstock, T. A. Minshull, and J. R. Hopper (2008), Modelling the composition of melts formed during continental break-up of the North Atlantic, Earth Planet. Sci. Lett., 269, 248-258, doi:10.1016/j. eps1.2008.02.024.

Bond, G. C., and M. A. Kominz (1984), Construction of tectonic subsidence curves for the early Paleozoic Miogeocline, southern Canadian Rocky Mountains-Implications for subsidence mechanisms, age of breakup and crustal thinning, Geol. Soc. Am. Bull., 95, 155-173.

Bond, G. C., and M. A. Kominz (1991), Disentangling middle Paleozoic sea level and tectonic events in cratonic margins and cratonic basins of North America, J. Geophys. Res., 96, 6619-6639.

Boote, D. R. D., D. D. Clark-Lowes, and M. W. Traut (1998), Paleozoic petroleum systems of North Africa, in Petroleum Geology of North Africa, edited by D. S. Macgregor, R. T. J. Moody, and D. D. Clark-Lowes, vol. 132 of Special Publication, pp. 7-68, Geological Society, London.

Buiter, S. J. H., B. Steinberger, S. Medvedev, and J. L. Tetreault (2012), Could the mantle have caused subsidence of the Congo Basin? Tectonophysics, 514-517, 62-80, doi:10.1016/j.tecto.2011.09.024.

Burgess, P. M. (2008), Phanerozoic evolution of the sedimentary cover of the North American craton, in The Sedimentary Basins of the United States and Canada, edited by A. D. Miall, vol. 5 of The Sedimentary Basins of the World, pp. 31-63, Elsevier, The Netherlands.

Burgess, P. M., M. Gurnis, and L. Moresi (1997), Formation of sequences in the cratonic interior of North America by interaction between mantle, eustatic and stratigraphic processes, Bull. Geol. Soc. Am., 108, 1515-1535.

Cammarano, F., P. Tackley, and L. Boschi (2011), Seismic, petrological and geodynamical constraints on thermal and compositional structure of the upper mantle: global thermochemical models, Geophys. J. Int., 187, 1301-1318, doi:10.1111/j.1365-246X.2011.05223.x.

Chang, H. K., R. O. Kowsman, A. M. F. Figueiredo, and A. A. Bender (1992), Tectonics and stratigraphy of the East Brazil rift system, an overview, Tectonophysics, 213, 97-138, doi:10.1016/0040-1951(92)90253-3.

Chopra, P. N., and M. S. Paterson (1984), The role of water in deformation of dunite, J. Geophys. Res., 89, 7861-7876.

Christensen, U. R. (1984), Convection with pressure and temperaturedependent non-Newtonian rheology, Geophys. J. Roy. Astron. Soc., 77, 343-384.

Cloetingh, S., and H. Kooi (1992), Intraplate stresses and dynamical aspects of rifted basins, Tectonophysics, 215, 167-185.

Coakley, B., and M. Gurnis (1995), Far-field tiliting of Laurentia during the Ordovician and constraints on the evolution of a slab under an ancient continent, J. Geophys. Res., 100, 6313-6327.

Conrad, C. P., and P. Molnar (1997), The growth of Rayleigh-Taylor-type instabilities in the lithosphere for various rheological and density structures, Geophys. J. Int., 129, 95-112.

Crosby, A. G., S. Fishwick, and N. White (2010), Structure and evolution of the intracratonic Congo Basin, Geochem. Geophys. Geosyst., 11, Q06010, doi:10.1029/2009GC003014.

Forte, A., J. Mitrovica, R. Moucha, N. Simmons, and S. Grand (2007), Descent of the ancient Farallon slab drives localized mantle flow below the New Madrid seismic zone, Geophys. Res. Lett., 34, L04308, doi:10.1029/2006GL027895.

Fowler, S. R., R. S. White, G. D. Spence, and G. K. Westbrook (1989), The Hatton Bank continental margin-II. Deep structure for two-ship expanding spread seismic profiles, Geophys. J. Int., 96, 295-309.

Goes, S., and S. van der Lee (2002), Thermal structure of the North American uppermost mantle inferred from seismic tomography, J. Geophys. Res., 107, 11,159-11,169, doi:10.1029/1999JB900300.

Goetze, C., and B. Evans (1979), Stress and temperature in the bending lithosphere as constrained by experimental rock mechanics, J. Roy. Astron. Soc., 59, 463-478.

Goutorbe, B., L. Drab, N. Loubet, and F. Lucazeau (2007), Heat flow of the eastern Canadian rifted continental margin revisited, Terra Nova, 19, 318-386, doi:10.111/j.1365-3121.2007.00750.x.
Griffin, W. L., S. Y. O’Reilly, J. C. Afonso, and G. C. Begg (2009), The composition and evolution of lithospheric mantle: A re-evaluation and its tectonic implications, J. Petrol., 50, 1185-1204, doi:10.1093/petrology/ egn033.

Hardebol, N. J., R. N. Pysklywec, and R. Stephenson (2012), Small-scale convection at a continental back-arc to craton transition: Application to the southern Canadian Cordillera, J. Geophys. Res., 117, B01408, doi:10.1029/2011JB008431.

Hartley, R. W., and P. A. Allen (1994), Interior cratonic basins of Africa: Relation to continental break-up and role of mantle convection, Basin Res., 6, 95-113.

Heller, P. L., C. M. Wentworth, and C. W. Poag (1982), Episodic post-rift subsidence of the United States Atlantic continental margin, Geol. Soc. Am. Bull., 93, 379-390.

Hillis, R. R., et al. (2008), Cenozoic exhumation of the southern British Isles, Geology, 36, 371-374, doi:10.1130/G24699A.1.

Hirth, G., and D. L. Kohlstedt (1996), Water in the oceanic upper mantle: Implications for rheology, melt extraction and the evolution of the lithosphere, Earth Planet. Sci. Lett., 144, 93-108.

Hirth, G., R. L. Evans, and A. D. Chave (2000), Comparison of continental and oceanic mantle electrical conductivity: Is the Archean lithosphere dry?, Geochem. Geophys. Geosyst., 1, 1030, doi:10.1029/ 2000GC000048.

Holbrook, W. S., et al. (2001), Mantle thermal structure and active upwelling during continental breakup in the north Atlantic, Earth Planet. Sci. Lett., 190, 251-266.

Holfard, S. P., R. R. Hillis, M. Hand, and M. Sandiford (2011), Thermal weakening localizes intraplate deformation along the southern Australian continental margin, Earth Planet. Sci. Lett., 305, 207-214, doi:10.1016/j. eps1.2011.02.056.

Hopper, J. R., T. Dahl-Jensen, W. S. Holbrook, H. C. Larsen, D. Lizarradle, J. Korenaga, G. M. Kent, and P. B. Kelemen (2003), Structure of the SE Greenland margin from seismic reflection and refraction data: Implications for nascent spreading centre subsidence and asymmetric crustal accretion during North Atlantic opening, J. Geophys. Res., 108(B5), 2269, doi:10.1029/2002JB001996.

Huismans, R., and C. Beaumont (2011), Depth-dependent extension, twostage breakup and cratonic underplating at rifted margins, Nature, 473, 74-78, doi:10.1038/nature09988.

Huppert, H. E. (1982), The propagation of two-dimensional and axisymmetric viscous gravity currents over a rigid horizontal surface, J. Fluid Mech., 121, 43-58.

Japsen, P., and J. A. Chalmers (2000), Neogene uplift and tectonics around the North Atlantic: Overview, Global and Planetary Change, 24, $165-173$.

Japsen, P., J. M. Bonow, P. F. Green, P. R. Cobbold, D. Chiossi, R. Lilletviet, L. P. Magnavita, and A. Pedreira (2012), Episodic burial and exhumation in NE Brazil after opening of the South Atlantic, Geological Society of America Bulletin, 124, 800-816, doi:10.1130/B30515.1.

Jaupart, C., and J. Mareschal (2011), Heat Generation and Transport in the Earth, Cambridge University Press, Cambridge, UK.

Jaupart, C., J. C. Mareschal, L. Guillou-Frotter, and A. Davaille (1998), Heat flow and thickness of the lithosphere in the Canadian shield, J. Geophys. Res., 103, 15,269-15,286.

Jaupart, C., P. Molnar, and E. Cottrell (2007), Instability of a chemically dense layer heated from below and overlain by a deep less viscous fluid, J. Fluid Mech., 572, 433-469, doi:10.1017/S0022112006003521.

Jordan, T. H. (1975), The continental tectosphere, Reviews of Geophysics, 13, $1-12$.

Jordan, T. H. (1981), Continents as a chemical boundary layer, Philosophical Transactions of The Royal Society, A, 301, 359-373.

Kadima Kabongo, E., S. S. M. Ntabwoba, and F. Lucazeau (2011), A Proterozoic-rift origin for the structure and the evolution of the Congo basin., Earth Planet. Sci. Lett., 304, 240-250, doi:10.1016/j. eps1.2011.01.037.

Karner, G. D. (1985), Effects of lithospheric in-plane stress on sedimentary basin stratigraphy, Tectonics, 5, 573-588.

King, S. D., and D. L. Anderson (1998), Edge-driven convection, Earth Planet. Sci. Lett., 160, 289-296.

Klein, G. D., and A. T. Hsui (1987), Origins of intracratonic basins, Geology, 15, 1094-1098.

Korenaga, J., and S. I. Karato (2008), A new analysis of experimental data on olivine rheology, J. Geophys. Res., 113, doi:10.1029/2007JB005100.

Korenaga, T., and J. Korenaga (2008), Subsidence of normal oceanic lithosphere, apparent thermal expansivity, and seafloor flattening, Earth Planet. Sci. Lett., 268, 41-51, doi:10.1016/j.eps1.2007.12.022.

Lee, C. A. (2003), Compositional variation of density and seismic velocities in natural peridotites at STP conditions: Implications for seismic imaging of compositional heterogeneities in the upper mantle, J. Geophys. Res., 108(B9), 2441, doi:10.1029/2003JB002413. 


\section{ARMITAGE ET AL.: INSTABILITY OF PASSIVE MARGINS}

Lee, C. A., P. Luffi, and E. J. Chin (2011), Building and destroying continental mantle, Annual Review of Earth and Planetary Science, 39, 59-90, doi:10.1146/annurev-earth-040610-133505

Lenardic, A., and W. M. Kaula (1993), A numerical treatment of geodynamic viscous flow problems involving the advection of material interfaces, J. Geophys. Res., 98, 8243-8260.

Lévy, F., and C. Jaupart (2011), Temperature and rheological properties of the mantle beneath the North American craton from an analysis of heat flux and seismic data, J. Geophys. Res., 116, B01408, doi:10.1029/ 2010JB007726.

Lindsay, J. F. (2002), Supersequences, superbasins, supercontinentsEvidence from the Neoproterozoic-Early Palaeozoic basins of central Australia, Basin Research, 14, 207-223.

Lindsay, J. F., R. J. Korsch, and J. R. Wilford (1987), Timing and breakup of a Proterozoic supercontinent: Evidence from Australian intracratonic basins, Geology, 15, 1061-1064.

Louden, K. E., J. C. Sibuet, and J. P. Foucher (1991), Variation in heat-flow across the Goban Spur and Galicia Bank continental margins, J. Geophys. Res., 96, 16,131-16,150.

Louden, K. E., B. E. Tucholke, and G. N. Oakey (2004), Regional anomalies of sediment thickness, basement depth and isostatic crusta thickness in the North Atlantic Ocean, Earth Planet. Sci. Lett., 224, 193-211.

Lucazeau, F., et al. (2008), Persistent thermal activity at the Eastern Gulf of Aden after continental break-up, Nat. Geosci., 1, 854-858.

Mareschal, J. C., A. Poirier, F. Rolandone, G. Bienfait, C. Gariepy, R. Lapointe, and C. Jaupart (2000), Low mantle heat flow at the edge of the North American continent, Voisey Bay, Labrador, Geophys. Res. Lett., 27, 823-826.

McKenzie, D. P., and M. J. Bickle (1988), The volume and composition of melt generated by extension of the lithosphere, J. Petrol., 29, 625-679.

Mei, S., and D. L. Kohlstedt (2000), Influence of water on plastic deformation of olivine aggregates 2. Dislocation creep, J. Geophys. Res., 105 21,471-21,481.

Mitrovica, J. X., and A. M. Forte (1997), Radial profile of mantle viscosity: Results from the joint inversion of convection and postglacial rebound observables, J. Geophys. Res., 102, 2751-2769.

Mitrovica, J. X., C. Beaumont, and G. T. Jarvis (1989), Tilting of continental interiors by the dynamical effects of subduction, Tectonics, 8 , 1079-1094

Moresi, L., and V. Solomatov (1998), Mantle convection with a brittle lithosphere: Thoughts on the global tectonic styles of the Earth and Venus, Geophys. J. Int., 133, 669-682.

Moresi, L., and V. S. Solomatov (1995), Numerical investigation of 2D convection with extremely large viscosity variations, Physics of Fluids, 7, 2154-2162.

Moresi, L., S. Zhong, and M. Gurnis (1996), The accuracy of finite element solutions of Stokes' flow with strongly varying viscosity, Physics of the Earth and Planetary Interiors, 97, 83-94.

Moucha, R., A. M. Forte, J. X. Mitrovica, D. B. Rowley, S. Quéré, N. A. Simmons, and S. P. Grand (2008), Dynamic topography and long-term sea-level variations: There is no such thing as a stable continental platform, Earth Planet. Sci. Lett., 271, 101-108, doi:10.1016/j.eps1.2008.03.056.

Nielsen, T. K., and J. R. Hopper (2004), From rift to drift: Mantle melting during continental breakup, Geochem. Geophys. Geosyst., 5, Q07003, doi:10.1029/2003GC000662

Nikishin, A. M., P. A. Ziegler, D. Abbott, M. F. Brunet, and S. Cloetingh (2002), Permo-triassic intraplate magmatism and mantle dynamics, Tectonophsics, 351, 3-39.

Nikolaeva, K., T. V. Gerya, and F. O. Marques (2011), Numerical analysis of subduction initiation risk along the Atlantic American passive margins, Geology, 39, 463-466, doi:10.1130/G31972.1.

O'Neill, C. J., A. Lenardic, W. L. Griffin, and S. Y. O'Reilly (2008), Dynamics of cratons in an evolving mantle, Lithos, 102, 12-24, doi:10.1016/j.lithos.2007.04.006.

Pattle, R. E. (1959), Diffusion from an instantaneous point source with a concentration-dependent coefficient, Quarterly Journal of Mechanics and Applied Mathematics, 12, 407-409.

Poag, C. W., and W. D. Sevon (1989), A record of Appalachian denudation in postrift Mesozoic and Cenozoic sedimentary deposits of the U.S. middle Atlantic continental margin, Geomorphology, 2, 119-157.

Poudjom Djomani, Y. H., S. Y. O'Reilly, W. L. Griffin, and P. Morgan (2001), The density structure of subcontinental lithosphere through time, Earth Planet. Sci. Lett., 184, 605-621.

Priestly, K., and D. McKenzie (2006), The thermal structure of the lithosphere from shear velocities, Earth Planet. Sci. Lett., 244, 285-301, doi:10.1016/j.eps1.2006.01.008.

Pritchard, D., G. G. Roberts, N. J. White, and C. N. Richardson (2009), Uplift histories from river profiles, Geophys. Res. Lett., 36, doi:10.1029/ 2009GL040928.
Ramsay, T., and R. Pysklywec (2011), Anomalous bathymetry, 3D edge driven convection, and dynamic topography at the western Atlantic passive margin, Journal of Geodynamics, 52, 45-56, doi:10.1016/j. jog.2010.11.008.

Sandiford, M., and D. L. Egholm (2008), Enhanced intraplate seismicity along continental margins: Some causes and consequences, Tectonophysics, 457, 197-208, doi:10.1016/j.tecto.2008.06.004

Saunders, A. D., R. W. England, M. K. Reichow, and R. V. White (2005) A mantle plume origin for the Siberian traps: Uplift and extension in the East Siberian Basin, Russia, Lithos, 79, 407-424, doi:10.1016/j. lithos.2004.09.010

Schutt, D. L., and C. E. Lesher (2006), Effects of melt depletion on the density and seismic velocity of garnet and spinel lherzolite, J. Geophys. Res., 111, B05401, doi:10.1029/2003JB002950.

Selley, R. C. (1972), Diagnosis of marine and non-marine environments form the Cambro-Ordovician sandstones of Jordan, Journal of the Geological Society, London, 128, 135-150.

Shahnas, M. H., and R. N. Pysklywec (2004), Anomalous topography in the western Atlantic caused by edge-driven convection, Geophys. Res. Lett., 31, L18611, doi:10.1029/2004GL020882.

Shapiro, S. S., B. Hager, and T. H. Jordan (1999), Stability and dynamics of the continental tectosphere, Lithos, 48, 115-133.

Shaw, R. D., M. A. Etheridge, and K. Lambeck (1991), Development of the late Proterozoic to mid-Paleozoic, intracratonic Amadeus Basin in central Australia: A key to understanding tectonic forces in plate interiors, Tectonics, 10, 688-721.

Sleep, N. H. (2005), Evolution of the continental lithosphere, Annual Reviews of Earth and Planetary Science, 33, 369-393, doi:10.1146/ annurev.earth.33.092203.122643.

Sleep, N. H. (2007), Edge-modulated stagnant-lid convection and volcanic passive margins, Geochem. Geophys. Geosyst., 8, Q12004, doi:10.1029/2007GC001672.

Sloss, L. L. (1963), Sequences in the cratonic interior of North America, Geological Society of America Bulletin, 74, 93-114.

Sloss, L. L. (1988), Introduction, in Sedimentary Cover-North American Craton, edited by L. L. Sloss, vol. D-2 of The Geology of North America, pp. 1-3, Boulder, Colorado, Geological Society of America.

Sloss, L. L. (1991), The tectonic factor in sea level change: A countervailing view, J. Geophys. Res., 96, 6609-6617.

Soares, P. C., P. M. B. Landim, and V. J. Fulfaro (1978), Tectonic cycles and sedimentary sequences in the Brazilian intracratonic basins, Geological Society of America Bulletin, 89, 181-191.

Spasojevic, S., L. Liu, M. Gurnis, and R. D. Müller (2008), The case for dynamic subsidence of the US east coast since the Eocene, Geophys. Res. Lett., 35, L08305, doi:10.1029/2008GL033511.

Stoker, M. S., S. P. Holford, R. R. Hillis, P. F. Green, and I. R. Duddy (2010), Cenozoic post-rift sedimentation off northwest Britain: Recording the detritus of episodic uplift on a passive continental margin, Geology, 38, 595-598, doi:10.1130/G30881.1.

van Balen, R. T., P. A. van der Beek, and S. A. P. L. Cloetingh (1995), The effect of rift shoulder erosion on stratal patterns at passive margins: Implications for sequence stratigraphy, Earth Planet. Sci. Lett., 134, 527-544.

van Wijk, J., J. van Hunen, and S. Goes (2008), Small-scale convection during continental rifting: Evidence from the Rio Grande rift, Geology, 36, 575-578, doi:10.1130/G24691A.1.

van Wijk, J. W., W. S. Baldridge, J. van Hunen, S. Goes, R. Aster, D. D Coblentz, S. P. Grand, and J. Ni (2010), Small-scale convection at the edge of the Colorado Plateau: Implications for topography, magmatism, and evolution of Proterozoic lithosphere, Geology, 38, 611-614, doi:10.1130/ G31031.1.

Vogt, U., J. Makris, B. M. O’Reilly, F. Hauser, P. W. Readman, A. W. B. Jacob, and P. M. Shannon (1998), The Hatton Basin and continental margin: Crustal structure from wide-angle seismic and gravity data, J. Geophys. Res., 103, 12,545-12,566

Watts, A. B. (1989), Lithosphere flexure due to prograding sediment loads: implications for the origin of offlap/onlap patterns in sedimentary basins, Basin Research, 2, 133-144.

Watts, A. B., and M. Steckler (1979), Subsidence and eustasy at the continental margin of eastern North America, in Deep Drilling Results in the Atlantic Ocean: Continental Margins and Paleoenvironment: Ewing Series 3, pp. 218-234, Washington D.C., American Geophysical Union.

Watts, A. B., and S. Zhong (2000), Observations of flexure and the rheology of oceanic lithosphere, Geophys. J. Int., 142, 855-875.

Weertman, J., and J. R. Weertman (1975), High temperature creep of rock and mantle viscosity, Annu. Rev. Earth Planet. Sci., 3, 293-315.

Yuan, H., and B. Romanowicz (2010), Lithospheric layering in the North American craton, Nature, 466, 1063-1068, doi:10.1038/ nature09332. 